Please refer to and cite the published version: Matheson, C. M., Rimmer, R., \& Tinsley, R. (2014). Spiritual attitudes and visitor motivations at the Beltane Fire Festival, Edinburgh. Tourism Management, 44, 16-33. https://doi.org/10.1016/ j.tourman.2014.01.023

\author{
Spiritual attitudes and visitor motivations \\ at the Beltane Fire Festival, Edinburgh \\ Catherine M Matheson $^{(a)} \quad$ Russell Rimmer $^{(\text {b) }}$ and Ross Tinsley ${ }^{(c)}$
}

a - Division of Business, Enterprise and Management, School of Arts, Social Sciences and Management, Queen Margaret University, Edinburgh, Queen Margaret University Drive, Musselburgh, East Lothian EH21 6UU T: +44 (0) 1314740000 E: cmatheson@qmu.ac.uk

b - Hotel and Tourism Management Institute, 6174 Soerenberg, Kanton Luzern, Switzerland T:

+41 (0) 4148811 E: russell.rimmer@htmi.ch and School of Arts, Social Sciences and Management, Queen Margaret University, Edinburgh, Queen Margaret University Drive, Musselburgh, East Lothian EH216UU T: +44 (0) 1314740000 E: rrimmer@qmu.ac.uk

c - Hotel and Tourism Management Institute, 6174 Soerenberg, Kanton Luzern, Switzerland T:

+41 (0) $4148811 \mathrm{E}: \underline{\text { rtinsley@htmi.ch }}$

\title{
Acknowledgements
}

We would like to thank three reviewers for their comments, which helped us to enhance the paper. Photographs by Ross Tinsley. 


\begin{abstract}
Outside the peak season for tourism to Edinburgh, Scotland, during the evening of April $30^{\text {th }}$, visitors attend a festival with ancient pagan overtones. Frequently, the evening is cold and windy. Our objectives are to: identify motivations for attending the festival; trial questionnaire items on spiritual attitude; and assess whether spirituality might be relevant in assessing visitor intentions. The method of investigation involved exploration and confirmation phases to test structures in distinct sub-samples. Further, a strict approach was applied to identify factors that had theoretical value. Spirituality attitude is found to be a factor, as well as the motivations of cultural adventure and escape. Given the nature of the event, the time of year and composition of the audience, encouraging repeat visitation and using this to develop and manage Edinburgh's tourism strategy has potential. Recommendations are made to management.
\end{abstract}

Keywords: motivation, spiritual attitude, unconventional festival, tourism development

\title{
Highlights
}

$>$ At Winter's end, BFF recreates a pre-Christian festival with spiritual aspects

$>$ Spiritual attitude and the motivations cultural adventure and escape are key factors

$>$ The research involved EFA and CFA to test constructs in distinct sub-samples

$>$ There are management implications for BFF professionalisation and growth

$>$ Implications extend to the host city's festival strategy and beyond 


\section{Spiritual attitudes and visitor motivations at the Beltane Fire Festival, Edinburgh}

\section{Introduction}

Commentators have suggested that festivals and events can enhance destination image, diversify the attractions base and promote tourism development (Reid, 2006; Richards \& Palmer, 2010; Richards \& Wilson, 2004; Quinn, 2007, 2010). For example, Getz (2008: 403) argued that "events are an important motivator of tourism, and figure prominently in the development and marketing plans of most destinations". This is exemplified by Edinburgh in Scotland, which stages no fewer than twelve major festivals annually (Festivals Edinburgh, 2013), as well as smaller scale festivals such as the Beltane Fire Festival (BFF). In the context of competition for tourist visits, it is crucial that destination managers comprehend how potential visitor needs might be met, how potential visitors form decisions on destinations to visit and whether, having decided to visit, they could be satisfied to the point of making return visits. This is of central interest to managers of tourism destinations, and an understanding of this area is important in making contributions to theory.

Despite the substantive literature on visitor motivation, which is reviewed in the next section, there are challenges pertaining to the complexity and heterogeneity of tourist needs and the inter-relationship between motivation and other constructs, such as attitudes. With regard to the latter, there are calls to include visitor attitudes in studies of motivation and behaviour prediction. Gnoth (1997) suggested that attitudes are the foundation of understanding motivation and behaviour. Nonetheless, limited attention has been accorded to attitudes in many studies of tourist behaviour and decision making. From the perspective of tourism management, our starting point is that an examination of visitor attitudes, in tandem with motivations provides a rounded means to comprehend visitor intentions and consumption.

In the current research, visitor motivations and attitudes are investigated in the context of one Edinburgh festival, the BFF, which is held on the evening of April $30^{\text {th }}$. Frequently, this evening is cold with a chilling wind. The end of April is out of the most popular season for Scottish tourism, which spans the months July to September (VisitScotland, n.d.). In fact, the majority of the major Edinburgh festivals occur in August. Despite the timing of the event the BFF attracts tourists, as an earlier survey indicated that approximately a third of the audience are tourists (Gonzalez, 2007). BFF has spiritual roots emerging from its pagan history and which 
relate to the passage of the seasons and the coming fecundity of Spring and Summer (Frazer 1922). There are aspects of the BFF which relate to Bakhtin's (1984) conceptualisation of the carnivalesque. The current study focuses specifically on spiritual attitudes as earlier qualitative work on BFF (Matheson \& Tinsley, 2010) indicated that spirituality could be important in consumer decision-making.

The research objectives are to: identify motivations for attending the festival; trial questionnaire items on spiritual attitude; and, assess whether spirituality might be relevant in assessing visitor intentions. To achieve these objectives, a quantitative methodology, involving principal components analysis (PCA) and confirmatory factor analysis (CFA), is employed. As part of the method, commonly used approaches to determining the numbers of components (such as, the eigenvalue-one criterion and scree plots) are rejected, as set out in Section 3, in favour of more parsimonious approaches to deciding how many components should be included. Adopting this course means a more rigorous examination is possible of whether spirituality has a role among the BFF audience. This is documented in Section 4. In Section 5, the fulfilment of the research objectives are discussed. This is done in three ways: first, by providing an insight into tourism motivation and attitudes to spirituality within the milieu of an unorthodox event; second, by extending an understanding of motivation to incorporate the under-researched area of spiritual attitudes in the management literature; and third, by informing management as they develop the city's tourism calendar.

\section{Motivation, Attitude and Spirituality}

In this section, a review is provided of the literature on festival motivation, attitudes, spirituality, tourism and events.

\subsection{Festival Motivation}

Backman, Backman, Uysal and Sunshine (1995: 17) suggested that "motivation refers to a state of need, a condition that serves as a driving force to display different kinds of behaviour toward certain types of activities, developing preferences, arriving at some expected satisfactory outcome". Crompton and McKay (1997) identified three motivational frameworks to explain tourist behaviour: push-pull factors, Iso-Ahola's escape-seeking dichotomy and Maslow's needs hierarchy. These tourism-motivation frameworks have been used in the development of motivation scales by festival researchers. Uysal, Gahan and Martin (1993) adopted Mannel and 
Iso-Ahola's (1987) framework, which pivots on "escape" and "seeking" motivational forces. Crompton and McKay (1997) drew on the escape-seeking dichotomy and push-pull frameworks. In doing so, both Uysal et al (1993) and Crompton and McKay (1997) broke new ground in motivation studies. This can be exemplified by the frequent adoption, often with adaptations, of their respective motivational scales by subsequent researchers (Chang, 2006; Formica \& Uysal, 1996, 1998; Lee \& Beeler, 2009; Yolal, Çetinel \& Uysal, 2009; Yolal, Woo, Çetinel \& Uysal, 2012). Other researchers drew on the festivals and events literature to develop scales (Chang \& Yuan, 2011; Lee, 2000; McDowall, 2010; Schofield \& Thompson, 2007; Thompson \& Schofield, 2009).

Empirical studies have pursued overlapping "themes", ranging from demographics (Backman et al., 1995; Chang \& Yuan, 2011; Mohr, Backman, Gahan \& Backman, 1993; Park, Reisinger \& Kang, 2008; Uysal et al., 1993; Van Zyl \& Botha, 2004), satisfaction and behavioural intention (Lee \& Beeler, 2009; Schofield \& Thompson, 2007; Thompson \& Schofield, 2009), cross-cultural comparisons (Dewar, Meyer \& Li, 2001; Schneider \& Backman, 1996) to segmentation and visitor type (Formica \& Uysal, 1996, 1998; Lee, 2000; Lee, Lee \& Wicks, 2004). Some of this empirical work indicates that there are common or similar motivations, for example cultural exploration, family togetherness, socialisation, escape/equilibrium recovery, excitement and novelty (Chang, 2006; Crompton \& McKay, 1997; Formica \& Uysal, 1996; Li, Huang \& Cai, 2009; Mohr et al., 1993; Scott, 1996; Thompson \& Schofield, 2009; Van Zyl \& Botha, 2004; Yolal et al., 2012). Perhaps this might be expected, given the adaptation of existing scales associated with the factors listed above to a range of contexts. Such is the recurrence of certain motives that Lee et al. (2004) emphasised the pervasiveness of a core set of motivations, irrespective of themes or locations. In contrast, Nicholson and Pearce (2001: 460, italics added) concluded that "There is little evidence yet of generic event motivations". Moreover, "...the broad pattern is clearly that people go to different events for different reasons and that the majority are going to a particular event for what it offers rather than to an event in general" (Nicholson \& Pearce, 2001: p.458). In fact, changes in motivation according to event and visitor type are found in research involving more than one event. For example, Scott (1996) found that different levels of importance were attached to motivational factors at three festivals: at one, visitors rated nature appreciation as the most important motive, while those at the other two considered family togetherness to be the most significant factor. Similarly, Nicholson and Pearce's (2001) comparative study of four events 
highlighted variations in motivations, including the occurrence of event-specific factors, in addition to common factors.

Differences in motivation are also evident according to visitor type. In Scott's (1996) study, differences emerged between motivations of first-time and repeat visitors. Key differences have also been identified between domestic and international visitors. Lee (2000) identified significant differences between these visitor types to a Cultural Expo on five out of seven motivation factors. Furthermore, Lee (2000: 174) concluded that "for all motivation factors, the mean scores of foreign visitors were found to be consistently higher than those of domestic visitors". In Formica and Uysal's (1996) study on the Umbria jazz festival they classified visitors as being either out-of-the-region visitors or Umbria-region visitors. They found that Umbria-region visitors attached greater significance to socialisation, while out-of-the-region visitors placed more importance on entertainment (Formica \& Uysal, 1996). Faulkner, Fredline, Larson and Tomljenovic (1999) identified subtle differences in motivations for locals and nonlocals. Schofield and Thompson (2007) suggested that cultural variables were more important to international visitors while sports and family aspects were more significant for domestic visitors. These comparative studies convey the heterogeneity of visitors and, taken together with variations in motivating factors by event type, provide a case for investigating what influenced attendance among the BFF's mixed audience of tourists and local visitors.

There are preliminary considerations to undertaking such an investigation. First, there may be event-specific motivations, perhaps arising as additional factors or in place of motivations known to occur frequently. Examples are to be found in studies that identified the factors of sports attractions, local special events (Thompson \& Schofield 2009), taste and social status (Park, Reisinger \& Kang, 2008), music (Bowen \& Daniels, 2005), self-esteem (Van Zyl \& Botha, 2004), food and beverage (Van Zyl \& Botha, 2004), event attractions (Lee et al., 2004; Lee, 2000) and the appreciation of nature (Scott, 1996). In addition, push dimensions, for example, change (Park et al., 2008) and relaxation (Backman et al.1995), have been observed.

Second, there is a degree of variation in the structure of motivations (Thompson \& Schofield, 2009). As Nicholson and Pearce (2001: 456) noted in their comparative study, "it should be recalled that similarly labelled factors are not necessarily identical in terms of their groupings, and that the individual motivations do not load uniformly on the factors across the 
four events". Indeed, this variation is seen in other studies. For example, a commonly used item "change of pace from everyday life" has loaded onto different factors, such as, socialisation and entertainment (Formica \& Uysal, 1998) and escape (Lee, 2000; Lee et al., 2004), illustrating Nicholson and Pearce's (2001) assertion that factors are not uniformly constructed.

There is a third preliminary consideration regarding not only common motives but also different theoretical perspectives. Perhaps the doubts of researchers such as Li and Petrick (2006) and Nicholson and Pearce (2001) on the existence of generic motivations arise because additional constructs and unidentified mechanisms have relevance in the contexts of at least some festivals. If so, investigations are required that draw on other theories in addition to tourist motivation frameworks. Potentially, sociology, psychology, marketing and sports marketing offer such an avenue (Li \& Petrick, 2006). Gyimóthy (2009) advocates the inclusion of cultural consumption theory and the sociology of leisure as means to develop the area. To date, responses to developing the field have tended to centre on incorporating behavioural constructs, such as, satisfaction and behavioural intention (Lee \& Beeler, 2009; Schofield \& Thompson, 2007; Thompson \& Schofield, 2009). An area which both tourism and festivals scholars have promoted is attitudes (Gnoth 1997; Hsu, Cai \& Li, 2010; Lee et al., 2004; Thompson \& Schofield, 2009; Zhou, Zhang \& Edelheim, 2013). In the following sub-sections, first attitudes and then spiritual attitudes are considered.

\subsection{Attitude}

For Ajzen (2005) attitude involves cognitive, affective and conative aspects. Cognition refers to a knowledge element involving belief or disbelief about an "object”, which can be people, products or services, but can also be a cause, issue or concept, such as striving to understand the ultimate truth of human existence. An emotional or affective response to an object can be positive or negative, such as feeling elated or disappointed, happy or sad. Subsequently, the pre-disposition to or likelihood of taking action in relation to an object is the conative aspect of an attitude. In a review of research on attitude, Ajzen and Fishbein (2000) conclude that most investigators assess attitudes via the evaluative element along dimensions determined by, for example, "approval or disapproval of a policy, liking or disliking of a person or group of people, and judgments of any concept" (Ajzen \& Fishbein, 2000:3). However, according to Ajzen and Fishbein (2000), in contemporary research affective states are measured in physiological terms 
or by using lists of mood adjectives or inventories. That is, they perceive a distinction in measurement between assessing attitude and affective states. In terms of the current research, as explained below, we had little time in which to administer an instrument to the BFF audience and so pursued the evaluation of spiritual attitudes only.

Attitudes are learned predispositions and are thought to be relatively consistent with the behaviour they reflect (Schiffman \& Kanuk, 2010). However, while consistency is a common characteristic of attitudes, this does not imply permanence necessarily. Attitudes can change over time and, further, events or situational influences may affect the relationship between attitude and behaviour (Schiffman \& Kanuk, 2010). There is research in the tourism area that explores behavioural intention, such as the studies of Lam and Hsu $(2004,2006)$ and Sparks (2007) on the behavioural intentions of wine tourists and potential travellers. In addition, there are tourism studies examining the attitudes of business owners (Frey \& George, 2010), residents (Lepp, 2007; Vargas-Sánchez, Porras-Bueno \& Plaza-Mejía, 2011) and tourists (Chang, Kiela \& Mak, 2010). Despite these advances, there are gaps in the tourism and events fields, particularly in the joint study of motivations and attitudes.

Gnoth (1997: 286) advocated a holistic approach to tourist motivation and argued that "attitudes have to be...captured and categorised within a completed and multidimensional system that reflects their structural diversity regarding expectations and experiences of attitude objects and... presented within a theory permitting a straightforward application for tourism planning and management of resources and experiences". As such this would allow festival organisers to tackle attitude dimensions together with the motivations that influence attendance and experience. There is evidence of a relationship between motivation and attitudes (Luo \& Deng, 2008) and that attitude, motivation and image can significantly predict future behaviour and tourist satisfaction (Lee, 2009). Hsu et al. (2010) found that motivation had a moderating influence on the relationship between attitude and expectation and, further, that motivation has an effect on attitude to visiting a destination. However, for visitors to calligraphic sites in China, Zhou et al. (2013) found no evidence that motivation and attitude were related, although this may be associated with fading awareness of traditional cultural pursuits such as calligraphy. It would seem then that in the tourism literature there is uncertainty about whether attitudes matter and what form this influence might take, even though the theory of consumer behaviour emphasises attitudes. 
Existing work is primarily located within the tourism field and limited attention has been accorded to festivals with mixed audiences of tourists and locals. This being the case there is considerable value in acquiring an insight into festival-visitor attitudes. For as Gursoy, Spangenberg and Rutherford (2006: 280) argued, visitors' perceptions, "attitudes towards festivals and their corresponding attendance, formation of future attendance intentions, and likelihood of suggesting that others attend are logically linked". In the current study, motivation is investigated in concert with spiritual attitudes, which are considered next. This study of BFF is undertaken in its Western cultural setting, where it is recognised personalised spirituality appears to be rising as expressions of spirituality through formalised religious observance decline (Hill et al., 2000). This will mean that attitudes investigated at BFF reflect underlying societal values, culturally bound notions and the changing role of spirituality (de Mooij, 2010).

\subsection{Spirituality and religion, tourism and events}

To understand spiritual attitude it is important to define the concept of spirituality. To do this we follow Hill et al. (2000: 52) who argued that "both spirituality and religion are complex phenomena, multi-dimensional in nature, and any single definition is likely to reflect a limited perspective or interest". They point to increasing secularisation in Western societies and a major cultural shift in the Western landscape, with the importance of religion decreasing, while expressions of spirituality in a more private and personal context are increasing. In line with this perspective, Elkins et al. (1988) cautioned that defining spirituality is a difficult task due to its complex, multi-dimensional and constructed nature. Ashley (2007) concurred, suggesting a broad approach be taken to spirituality thus allowing for individual interpretation or self-definition and which permits defining characteristics to be observed such as search for meaning, connection and inter-relationship, self-transcendence, and compassion. Kale (2004: 93) pointed towards the increasingly individualised nature of spirituality among consumers, "the engagement to explore - and deeply and meaningfully connect one's inner self - to the known world and ... Beyond".

However, Hill et al. (2000) caution that consideration of the sacred is central to an understanding of spirituality. Drawing on the works of Principe (1983), Titmuss (2000) and Kumar (2000), Ashley (2007) reported the word religion denoted being bounded by a certain belief system, whereas we adopt Hill et al.'s (2000: 66) definition of spirituality as "the feelings, 
thoughts, experiences, and behaviours that arise from the search for a sacred", where "the term 'search' refers to attempts to identify, articulate, maintain or transform" and "sacred' refers to a divine being, divine object, Ultimate Reality, or Ultimate Truth as perceived by the individual".

This definition of spirituality by Hill et al (2000) incorporates the aspects of cognition (in the form of thoughts or beliefs), affects (in the form of feelings) and conation (behaviours that arise) identified by Ajzen (2005) in defining attitude. Therefore, in this paper the term "spiritual attitude" refers to this interpretation of Hill et al's (2000) definition of spirituality in the form of the three-aspect definition of attitude. However, in terms of implementation, we concentrate on evaluation, which reflects contemporary research practice (Ajzen \& Fishbein, 2000). For instance, in terms of a statement in the instrument (Appendix 1), if an individual thinks or believes strongly that all life is interconnected then this would be a judgement or evaluation of a spiritual attribute as envisaged by Ajzen and Fishbein (2000).

Spirituality has been investigated in a variety of contexts including the New Age movement, pilgrimage tourism, and festivals and events. Zinnbauer, Pargament and Scott (1999) found those with an interest in the New Age identified with the term spirituality but not religiousness. Timothy and Conover (2006) pointed to the New Age movement's growth as a reflection of dissatisfaction with more traditional religion and with the pace of contemporary Western society. The movement is complex with an assortment of practices, borrowing and interpreting from a wide range of ancient beliefs, with particular reverence for nature, such as the ancient reverence of the Beltane ritual for the fecundity and healing powers of nature. The New Age movement lacks a central authority, emphasising the individual's own spiritual quest. Willson (2011) found travel, perhaps to a spiritual centre, acted as an instrument of healing from the excesses of secular and materialistic environments, so assisting in quests for inner peace. While the emphasis is on inner journeys of discovery and transformation, these journeys are often physically manifested as pilgrimage to sites relating to ancient cultures, nature and healing.

Spirituality is considered widely in pilgrimage tourism (Cohen, 1998; Digance, 2003; Fleischer, 2000; Murray \& Graham, 1997; Nolan \& Nolan, 1992; Olsen \& Timothy, 2006; Shuo, Ryan \& Liu, 2009; Vukonić, 1992). Pilgrimage is recognised as the earliest form of tourism and there is a conceptualisation of contemporary tourism as secular pilgrimage (Graburn, 1989; 
Rinschede, 1992). Drawing on Van Gennep (1960), Graburn (2001) considered tourism as a metaphorically sacred and liminal experience, particularly rites of passage style tourist experiences. However, he acknowledged that most tourists are, in general, not changed by their experience and seek a lifestyle not too dissimilar to home. Perhaps visitors to BFF differ in this regard - or alternatively seek or embrace lifestyles that other tourists do not. If so, they may be more open to spiritual centres and spirituality, as propounded by Willson (2011), Manzo (2003) and Cohen (1979).

Collins-Kreiner (2010: 446) argued that "differences between tourism and old-fashioned pilgrimage are narrowing", citing New Age travel as "a growing market for pilgrimage, personal growth and non-traditional spiritual practices" (Collins-Kreiner, 2010: 445). For Sharpley and Jepson (2011: 55), working in the contexts of the rustic and tourism, spirituality is "a connection between the self and the 'this world', implying that a spiritual or emotional relationship exists or is sought between people, 'this world' and specific places... within it". Given the bucolic origins of the BFF and the concentration of authors highlighting interconnectedness, self-transcendence and growing spiritually, we used an instrument that draws on spiritual maturity to obtain items for the current investigation (Astin, Astin \& Lindholm, 2011).

In terms of festivals and events, those with spiritual aspects that have been analysed (Gallarza, Arteaga, Floristán \& Gil, 2009; Misetic \& Sabotic, 2006) tended to concentrate on approaches in the existing motivation literature. For example, McDowall's (2010) work on attendance at a Hindu-Buddhist festival in Thailand did not consider the role of spirituality or religion. One study that did highlight the significance of spirituality is Partridge's (2006) study of the British free festival scene (see also Sherry \& Kozinets, 2007). Nevertheless, Sharpley and Jepson's (2011: p.53) remark that "few attempts have been made to verify the claim that individuals seek or experience spiritual fulfilment through tourism" can also be extended to festivals and events.

Given the paucity of relevant research involving spirituality, tourism and festivals, we turned to another source, the project Spirituality in Higher Education (SHE) at University of California. For more than a decade, SHE researchers have evaluated undergraduate and staff attitudes to religion and spirituality at colleges and universities across the USA. As part of their endeavours, they reviewed definitions and approaches in a range of disciplines including 
business, education, psychology and measurement theory, health and sociology. Two researchers at SHE, Lindholm and Astin (2008: 64), wrote that "while the semantic interpretation of the word spirituality is clear, its meaning in operational terms is more ambiguous". In Section 3.2 on instrument design, we concentrate on their notion of "spiritual maturity" (Astin et al., 2011: 58) or "ecumenical worldview" (Bryant, 2007: 839), in which life is interconnected, everybody is spiritual, love underpins the main religions, and personal spiritual growth does not depend on being religious or actively involved in a religion. In operational terms, we adopt the contemporary approach of evaluating attitudes to statements on these aspects of spirituality.

\section{Research Setting and Method}

\subsection{Beltane Fire Festival}

The BFF dates to pre-Christian Irish and Scottish festivals. Similar festivals were celebrated in other European nations (Frazer, 1922). The name "Beltane" is thought to originate from a Gaelic-Celtic word meaning "bright/sacred fire" (BFS, 2007). Manson (2006) suggested that three types of rituals are celebrated by neo-pagans: first, rites of passage which can comprise ceremonies marking, for example, the move from adolescence to adulthood; second, initiation rites which could engender a spiritual awakening in the individual and provide a connection to the group; and, third, seasonal festivals which are tied to changes in nature and of which there are seven (Samhain, Yule, Imbolc, Ostara, Midsummer, Lughnasadh and Mabon) in addition to Beltane. Of these, the Samhain and Beltane festivals are most important to neopagans (Manson, 2006). In the case of Beltane, its origins lie in the celebration of spring and the fertility of land, livestock and people (BFS, 2007; Frazer, 1922). A common feature of Beltane festivals was the 'Need-Fire', which was lit by a spiritual figurehead (BFS, 2007). From this source, communal bonfires were lit and individual home fires were re-lit (BFS, 2007). They were perceived to have a symbolic fertilising influence (Frazer, 1922). It was known that, "plenty of beer and whisky" might be brought along (Frazer, 1998: 719) and consumed (Livingstone, 2000). It appears such festivities were discouraged and almost all were discontinued in the $19^{\text {th }}$ century: "The history of the custom can be traced from the early Middle Ages, when it was denounced by the Church as a heathen superstition, down to the first half of the nineteenth century, when it was still occasionally practised in various parts of Germany, England, Scotland, and Ireland" (Frazer, 1922: 638). In Scotland, of those that remained into the nineteenth century, only the Edinburgh Beltane survived into the early twentieth century (BFS, 2011). 
Historically, the festival date was probably determined from the astronomical calendar to fall between the Spring equinox and the Summer solstice (Dames, 1992). The festival now occurs annually on the $30^{\text {th }}$ April (BFS, 2012) on Calton Hill, Edinburgh. A community cultural group resurrected the festival in the late 1980s, providing a contemporary reinterpretation. Initially, the event was free but festival growth and increasing pressure from external regulatory bodies led to a paid ticketing model. In effect, the audience numbers grew from a few hundred to thousands. Approximately 300 performers take part and, in 2011, approximately 8,500 people attended (see Figure 1). It takes place outdoors and there are uninhibited aspects of the performance, which includes a procession, fire rituals, drumming and performance groups. The BFS (Beltane Fire Society), a charitable organisation consisting almost entirely of volunteers, oversees the event, which it promotes primarily through press coverage, flyers and the web. The festival takes place in the low season in Edinburgh's events calendar. Nevertheless, it attracts tourists (Gonzalez, 2007).

\section{Fig1Performance.tiff (NEAR HERE)}

Central to the BFF are the May Queen and the Green Man, with the May Queen being the personification of "purity, strength and the potential for growth" and "the energy of the earth"; whereas the Green Man is in "a dormant and inactive state" until his re-birth as a young man, representing vibrancy and the coming of a new summer (BFS, 2007). The procession of the May Queen and her White Guard of warriors acts as a vehicle to tell the story of the BFF ritual (Figure 2), which includes the re-birth of the Green Man.

\section{Fig2MayQueen.tiff (NEAR HERE)}

A variety of other characters are involved. For example, the Blues are the elders of the festival and have both practical and spiritual responsibilities. They ensure order on April $30^{\text {th }}$; and during preparations they give practical guidance and assistance to performers and organisers (BFS, 2007). Another group, the Reds, are "spirits of chaos and disorder" and embody the carnivalesque as they represent "the world Turn'd Upside Down - the one night of the year where fools become kings... and a personification of the need in all of us to let loose and go wild just once in our lives" (BFS, 2007). The Reds seek to "disrupt the procession with 
their lewd and lascivious behaviour" (BFS, 2012). Musical accompaniment is provided by the Red Beastie Drummers.

\subsection{Instrument design and data collection}

Instrument design was constrained by the nature of the event and the available timescale for data collection. BFF is a single evening event characterised by a fluid performance structure executed after dark with little lighting. Consequently, there was a limited timeframe for data collection. Furthermore, it was difficult to conduct a pilot with an audience at this "shortduration event" (Raybould, Digance \& McCullough, 1999: 205), although an initial round of spirituality statements was tested with members of BFS, many of whom first encountered the BFF as audience members in earlier years.

A questionnaire was constructed drawing on previous studies (Appendix 1). Sixteen relevant motivation statements were included. These were drawn from the festival literature such as, Crompton and McKay (1997) and Lee et al. (2004) and adapted for the context. For example, the statement, "When at Beltane, I like to 'let my hair down'" was adapted from Crompton and McKay's (1997) statement “When at Fiesta, I like to 'let my hair down”'. For both audience and performers, the festival can provide a temporary period of release from social mores. Spirituality statements were drawn from the SHE project in the USA (Astin, Astin \& Lindholm, 2011; Astin \& Keen, 2006; Bryant \& Astin, 2008).

The SHE team designed questions that respondents could answer meaningfully regardless of their belief systems, in which references to "God", "Supreme Being" and such like terms were minimised (allowing respondents to conceptualise what the concepts meant for them) and in which "specific denominational or sectarian terminology would be avoided (for example, 'sacred texts' was used instead of 'Bible' or 'Koran')” (Astin et al., 2011: 41). Given this care in wording statements and, in addition, accommodating the possibility that searching for the sacred might occur separately from religious belief and practice, it seemed the work of the SHE team afforded a means of measuring spiritual attitude among the Beltane audience. This was decided after considering the results of a small survey by Gonzalez (2007), in which it was found the BFF audience was young and well-educated, providing at least demographic parallels in terms of age, socio-economic classifications and occupations with those of the students and staff of colleges and universities in the US. On this basis and given the care at SHE in framing 
statements, it seemed that an initial attempt to use items from the SHE at BFF was warranted, notwithstanding the possibility of differences in the spiritual landscapes of the US and the BFF audience.

SHE researchers identified seven components measuring spirituality and related qualities, for which they established reliability and validity (Lindholm \& Astin 2008; Astin, et al., 2011). An instrument for BFF would be too long, given the available time for surveying respondents, if all seven were included. However, an important component was noted as "the process of continually transcending one's current locus of centricity" (Astin, et al., 2011: 58; Love \& Talbot, 2005: 365). That is, "recognising concerns beyond oneself" (Bryant, 2007: 835) which is "in essence a manifestation of spiritual maturity" (Bryant, 2007: 836) or "ecumenical worldview" (Astin, et al., 2011: 54). For the current investigation, four statements devised by SHE researchers (Spirituality in Higher Education, 2004) were used in the principal-components and confirmatory factor analyses, namely:

All life is interconnected

Love is at the heart of all great religions

We are all spiritual beings

Most people can grow spiritually without being religious

The BFF instrument contains other items derived from the SHE project, such as Nonreligious people can be just as spiritual as religious people and Pain and suffering are essential to becoming a better person. As can be seen in Table 1b of Section 4, the patterns of responses to them at BFF were polarised compared with responses to other SHE items and so they were not used in constructing a spirituality component. Also included in the instrument were statements about being on a quest, searching for meaning and purpose, self-ratings on spirituality along with "qualities that highly spiritual people would be expected to exemplify" (Astin et al., 2011: 52). These also were not included in the current investigation because, on the evidence from Astin et al. (2011), some of them may be assigned to a component with the four above or they may occur in another spirituality component. Not including those means we can test the existence of a role for spirituality using close to a minimum number of indicators. Our intention is to use the omitted spirituality items in other research on the BFF audience and its segmentation.

Twenty eight trained surveyors undertook onsite administration of the survey on 30 April 
2011. Surveyors approached every seventh to tenth person, endeavouring to alternate between genders and to approach only one person per group. Surveyors were distributed around the performance area and stationed at the two entry points to the festival site. The time available to administer the survey - from the gates being opened prior to festival commencement until darkness fell - was limited. Even so, 378 questionnaires were collected, of which 375 could be used.

\subsection{Analytical approach}

The surveys were coded and each given a numeric identifier. In 33 surveys, small numbers of responses to motivation and spirituality statements were missing (see Table 1b). Values were multiply imputed for missing fields to maintain sample size at 375 . The Amelia package was used, in line with its designers' recommendations, to produce five imputed samples (Blackwell, Honaker \& King 2012; King, Honaker, Joseph \& Scheve, 2001). With Amelia, small samples, high correlations, discrete variables, the presence of covariates, and the possible violations of assumptions on homoskedasticity and measurement error are treated rigorously (Blackwell et al., 2012; King et al., 2001). The distributional assumption is that variables are approximately multivariate normal. To attain this, responses to motivational and spirituality statements were subjected to natural log transformations and these were standardised. Skewness and kurtosis are not excessive in the transformed data, being bounded above by the value 1.4 for all the items across the imputed datasets. It is recommended that skewness should not exceed 2.0 and kurtosis should not exceed 7.0 (Fabrigar, Wegener, MacCallum \& Strahan, 1999). Therefore the transformed items can be regarded as approximately normal for multiple imputation and for subsequent applications of CFA.

Given the nature of the research objectives, in particular whether there is a role for spirituality in the assessment of audience behaviour, exploratory analysis followed by a round of confirmation was undertaken. To carry this out, each imputed sample was divided randomly into two sub-samples: an "exploratory sub-sample" was allocated 176 instruments; and a "generalisable sub-sample" was allocated 199. Overall, the approach consists of three main stages, illustrated in Figure 3.

1. Allocate each survey case to one of the sub-samples. 
2. Apply PCA to extract components: first using only motivation items, determine the number of components to extract, then extract them; and second, using both the motivation and spirituality items determine number and extract components.

3. Assess whether the structures found in Stage 2 generalise in the corresponding generalisable sub-sample by: (i) applying PCA again; and (ii) undertaking CFA.

\section{Fig3TheAnalyticalApproach.docx (NEAR HERE)}

The reason for allocating numbers of respondents as we have to exploration and generalisation relates to the literature on sample size. Using an exploratory sub-sample and all 16 motivational items, there would be 11 responses per item. This exceeds the common requirement of 10 , while being more than twice the often-mentioned minimum of five (Fabrigar et al., 1999). If subsequently all 16 motivational statements as well as all four spirituality items were included, the number of survey responses per item would be 8.8 , somewhat below the benchmark of 10 , but still above the minimum of five. As will be seen below, all 20 items were not retained in PCAs, raising the number of responses per item well above the benchmark of 10. However, researchers have criticised guidelines on sample size because acceptable sample size is affected by component overdetermination and the communalities of items (Fabrigar et al., 1999). In the analysis that follows, overdetermination and communalities are monitored carefully. For CFA, the question arises of whether the generalisable sub-sample size of 199 is appropriate. Preliminary calculations for distinguishing between RMSEA (root mean square error of approximation) of zero and the conventional "stringent" (Hooper, Coughlan \& Mullen, 2008: 54) upper bound of 0.07 result in a sample size of 132, less than the allocated 199 (Preacher \& Coffman, 2006).

Depending on how many components are extracted, PCA may generate structures in which "minor components appear to be major" (Fabrigar et al., 1999: 278). In particular, the inclusion of spirituality - if it is only of minor concern - is to be avoided. Commonly, number of components to extract is decided using either scree plots or the eigenvalue-one criterion. The first can be ambiguous and the second is known to overestimate the number to extract (Fabrigar et al., 1999). Alternatively, researchers could unilaterally decide how many components to extract. Because such a decision might introduce a measure of researcher bias, there would again be scope for the unjustified extraction of a spirituality component. We rely instead on 
three approaches that are parsimonious in deciding the number of components. These are Horn's parallel analysis (PA) (Dinno, 2011; Hayton, Allen \& Scarpello, 2004), which is frequently held to be the most accurate method (Basto \& Pereira, 2012; Fabrigar et al., 1999; Schmitt, 2011); Velicer's MAP (minimum average partial correlation) approach (Basto \& Pereira, 2012); and the VSS approach (very simple structure, Revelle \& Rocklin, 1979).

Beyond taking decisions on numbers of components, validity should be considered. Researchers across a range of disciplines apply PCA for this purpose, for example Hsu, et al., (2010), Mohamad, Lo, Songan and Yeo (2012) and Perera and Vlosky (2013) in tourism; Evans et al., (2002) in psychotherapy; Gau (2011) in criminology; Astin et al., (2011) and Jordan (2001) in ethics, education and spirituality; Damitz, Manzey, Kleinman and Severin (2003) and Nako and Barnard (2012) in management assessment, leadership and HRM; and Reimers et al., (2012) in public health. Typically, items are entered into a PCA with no information provided on the agglomerations of items into constructs. Taking candidate constructs from PCAs, CFA provides a "strong" approach to validity (Braun, Woodley, Richardson \& Leidner, 2012: 4) compared with relying solely on PCAs. With CFA it is possible to test hypotheses regarding factor structure (Yu Chancellor \& Cole, 2011; Hsu et al., 2010; Kolar \& Zabkar, 2010) and assess validity. Following a number of researchers in the area we investigate convergent validity which is "the extent to which responses from alternative measurements of the same construct share variance", and discriminant validity which "refers to the degree to which two measures designed to measure similar, but conceptually different constructs are related" (Slavec \& Drnovšek 2012: 62).

On the surface, it appears that the PCAs in this investigation depart from accepted practice by involving both motivations and attitudes. However, as argued by Kline (1994), an important feature is the inclusion of items that load onto relevant constructs (in our case, motivations) and that are likely to differ from the target of study (spiritual attitude). ${ }^{1}$ To decide the composition of components, items were deleted if:

- their communalities were less than 0.5;

- loadings onto components were less than 0.5 ;

\footnotetext{
${ }^{1}$ Kline (1994: 103) further demonstrated why different scales should be included in the analysis of a target construct, using the example of a published study "where the inclusion of other scales radically transformed the interpretation of results" to the extent of demonstrating an instrument's lack of validity. He provides other examples of studies where the validity of a target construct is verified when additional, relevant, but different constructs are included. The literature cited in the current paper provides other examples from across a range of disciplines.
} 
- there were cross-loadings greater than 0.4 ; and

- differences were detected in loadings for the same item of less than 0.2 (Fabrigar et al., 1999; Field, 2009; Harrington, 2008).

Thereafter, varimax rotation was applied. Choosing PCA with varimax rotation is consistent with many endeavours in the festivals and tourism literature (Bowen \& Daniels, 2005; Chang, 2006; Dewar et al., 2001; Hsu et al., 2010; McDowall, 2010; Mohamad et al., 2012; Perera \& Vlosky, 2013; Scott, 1996; Van Zyl \& Botha, 2004). It might be objected that rather than apply PCA, EFA should be used. However, the intention was to remain in contact with the tourism literature that quantitatively explores dimension reduction with PCA.

In Stage 3 of Figure 3, the generalisable sub-samples are used for two analytical steps. First, PCA is performed using the structures determined in Stage 2. Second, CFA is carried out. The background to this is that PCA is a dimension-reduction approach that attempts to capture a substantial and meaningful amount of the variance among items, without using all possible components. CFA provides an opportunity to test the PCA structure and further to assess factor and error co-variation and seek cross-loadings. In the CFA, it was decided that if a crossloading or covariance were tested for inclusion, then it would be retained only if it were significantly different to zero at five per cent or better.

\section{Results}

In this section, results are presented for the PCAs and CFAs of Figure 3. Before this, descriptive statistics are presented in Tables $1 \mathrm{a}$ and $1 \mathrm{~b}$ for the 375 questionnaires included in the analysis.

\subsection{Descriptive statistics}

Table 1a contains background information on the audience. Note that over $95 \%$ of the respondents were white and more than half were younger than 30 . Of the 375 respondents, $51.9 \%$ were Edinburgh residents and $18.6 \%$ had travelled from elsewhere in Scotland. This means just fewer than $30 \%$ of those sampled travelled from outside Scotland. For this group, similar proportions travelled from elsewhere in the UK (12.5\% in Table 1) and Europe (11.2\%). As shown in Table 1a, the remainder (5.9\%) were citizens of more distant places, such as the US, Canada and Australia. 
Among the Scottish residents were 37 international students, most of whom had travelled from the USA or Canada to study in Scotland. They raised the proportion at BFF who were travellers (WTO, n.d.) and not "normally" resident in Scotland to 40\% approximately (in fact $39.5 \%$ ). Among non-Scottish residents, most said they came for leisure, to attend BFF and visit family and friends, with more being in Scotland for leisure than the other two reasons. In Table $1 \mathrm{a}$, it can be seen also that only $27.0 \%$ of people at Beltane were born in Scotland. Thus while about $70 \%$ of respondents resided in Scotland, many fewer than half of them were born there. Overall, $80.4 \%$ of all respondents are shown in Table 1a as not attending BFF previously. Also in the table, it can be seen that the majority of respondents came with friends. Somewhat more than a fifth attended with partners and about half of this proportion attended as part of a family group.

\section{Table1aPercentagedistributionofcharacteristics.docx (NEAR HERE) Table1bSummaryresponsestomotivationandspiritualitystatements.docx (NEAR HERE)}

Those surveyed were asked to nominate their religious faith. More than a third $(37.8 \%)$ replied 'none', with a further $16 \%$ responding agnostic, atheist or humanist (this last category including only a few respondents). That is, more than half of respondents rejected religious practice. Seven per cent said they were wiccan or pagan, affiliations having a special association with Beltane and its origins. Also, in total $76.6 \%$ of respondents only 'knew a little' $(43.2 \%)$ or had 'heard informally' (33.4\%) about Beltane. That is, less than a quarter, but more than three times the proportion of wiccans and pagans, claimed to understand the significance of what happens at BFF.

\subsection{Principal components analyses}

Tables 2 to 5 contain results for Stages 2 and 3 of the method. In Table 2 on number of components, the PA, MAP and VSS methods are compared with the eigenvalue-one criterion and also the results of applying the four methods to the data for the 165 individuals for whom imputation of missing data was not required. Across the exploratory and un-imputed sub-sets, PA, MAP and VSS agree that two components are required to explain the variation in motivation statements; when spirituality items are added, three components are required. Using the eigenvalue-one criterion always suggests extracting a larger number. To report PCA results 
across the five exploratory and generalisable sub-samples, averages are presented in Tables 3 and 4 (King et al., 2010).

\section{Table2Numberofprincipalcomponentstoextract.docx (NEAR HERE) Table3AveragevaluesforPCAoverexploratorysub-samples.docx (NEAR HERE) Table4 AveragevaluesforPCAovergeneralisablesub-samples.docx (NEAR HERE)}

Summary indicators are provided at the tops of Tables 3 and 4, beginning with the determinant values, which are indicators of inter-item correlation. They are small, but not so small as to introduce concerns about multicollinearity between item responses (Field, 2009). That is, the determinant values are consistent with the presence of substantial correlations between a number of items. The determinant becomes smaller when spirituality items are introduced. The reason can be seen in Figure 4 where correlations multiplied by 100 are presented for the first exploratory sub-sample. Darker 'squares' (one of size 4 cells $\times 4$ cells and two of size $3 \times 3$ ) edged in black straddle the diagonal. They represent correlations between items in the extracted components. While the two components involving motivation items are represented by relatively dark squares, spirituality items contribute another dark square and further bands of low item correlations, accounting for the reduction in the determinant. Additionally, the reported statistics for Bartlett tests of sphericity provide evidence that correlation matrices are not identities, and so are suitable for dimension reduction. Also shown are the overall Kaiser-Meyer-Olkin sampling adequacy statistics (KMO in the tables). Values greater than 0.6 are acceptable (Kaiser, 1970). These are not smaller than 0.738 across Tables 3 and 4. Individual-item sampling adequacies (shown in the lower panels of Tables 3 and 4 ) are greater than the accepted benchmark of 0.6. Two further indicators of overall performance are provided. The first is the number (and percentage) of estimated correlations that depart by more than 0.05 in value from observed values. Fewer than half of the non-redundant residuals are greater than 0.05 in Table 3, with the proportion for the three-component structure being smaller. In Table 4, the proportion of non-redundant residuals exceeds the benchmark of $50 \%$ for the two-motivation structure. The remaining overall indicator is the proportion of total variance explained. In Table 3, the values are close to $70 \%$; while in Table 4 they exceed $60 \%$.

\section{Fig4PatternsofCorrelationsExploratory.docx (NEAR HERE)}


Component structures are shown in the second and third panels of Tables 3 and 4 . The ordering of components in columns $\mathrm{C} 1$ to $\mathrm{C} 3$ reflects the variance explained by each. The main loadings in bold exceed 0.7 in Table 3, while in Table 4 the loading of the item "to seek adventure" is less than 0.7 , having value 0.636 in the lower panel. The motivation shown in $\mathrm{C} 1$ includes four large loadings and is named "escape" in the literature while another consists of three items, two from a component frequently named "cultural exploration" and one from another often named "novelty" in the literature. As the items involved are acquiring cultural knowledge, enjoying new experiences and seeking adventure, this component is named "cultural adventure". In component C2 in the third panels of Tables 3 and 4 only spirituality items have loadings that exceed 0.7 .

Guidelines on sample size are met. In the three-component structures, 10 items are involved, so for the exploratory sub-samples there are more than 17 responses per item. In the generalisable sub-samples, responses per item are greater still. Drawing on Fabrigar et al. (1999), the two- and three-component structures meet benchmarks on overdetermination. Also, average communalities over the main loadings are 0.548 or greater in Tables 3 and 4 . While smaller than the average communality of 0.7 declared appropriate for factor extraction in samples of size 100 , our sub-sample sizes are closer to 200 , which is desirable when average communalities are smaller (Davidson, Tripp, Fabrigar \& Davidson, 2008; Fabrigar et al., 1999).

Overall, Tables 3 and 4 suggest that there is a role for spirituality in concert with motivations in understanding the BFF audience. Further, tests conducted to check congruence (reported in Appendix 2) verify that the motivation components are not similar to each other and neither of these is similar to the spirituality construct.

\subsection{Are loadings generalisable?}

The results of Tables 3 and 4 suggest a three-component structure for the BFF audience, consisting of spirituality attitude and the motivations of escape and cultural adventure. However, inspection of Figure 5 for the first generalisable sub-sample makes clear that the pattern of item correlations for cultural adventure are smaller than shown in Figure 4 for the first exploratory sub-sample. Also, two forms of evidence on this motivation in Table 4 are weaker than for the other components. First the communality of the item "to seek adventure" is below 0.5. Had this occurred in the exploratory sub-samples, the item would have been omitted. However, in line 
with the analytical plan laid out in Section 3, it is retained to aid in assessing generalisability of findings. Consequently, average communalities in the two panels of Table 4 for the component containing it, cultural adventure, fall below 0.6. If the seek-adventure item were removed, the component would rely on only two items for its integrity and would not satisfy the minimum requirement for overdetermination (Fabrigar et al., 1999). Second, the values for Cronbach's $\alpha$ in Table 4 for cultural adventure falls below 0.6, suggesting the component should not be included in the structure for generalisable sub-samples. On the other hand, the spirituality component meets benchmarks for its inclusion in the exploratory and the generalisable subsamples. To study whether this conclusion is warranted, confirmatory factor analysis is reported next.

\section{Fig5PatternsofCorrelationsConfirmatory.docx (NEAR HERE)}

\subsection{Confirmatory factor analysis}

The three components emerging in PCAs were postulated as latent dimensions (factors) for a CFA study (Brown, 2006) in which it is possible to study linkages among measurement errors and assess cross-loadings from latent dimensions onto items assigned initially to other factors. Moreover, it is possible to analyse convergent and discriminant validity. The approach taken to CFA was to first run the model with the three factors from PCA allowing for correlations between them, so as to assess model fit and validity. Having done this, some fit statistics did not satisfy benchmark criteria. Hence, modification indices were used to seek ways of improving the model. Two rounds of calculating these indices were undertaken, from which an error correlation and one cross-loading improved model fit. This is the model reported in Table 5, showing at the foot of the table, the correlation of -0.152 between the statements "change of pace" and "to relieve boredom" and the loading 0.173 of cultural adventure onto the change-ofpace item. The model of Table 5 was estimated for the first generalisable sample. All goodnessof-fit benchmarks are satisfied. Those obtained with the other generalisable sub-samples agree closely on loadings, correlations, cross-loadings and fit statistics.

\section{Table5CFAresultsobtainedinthefirstgeneralisablesub-sample.docx.}


The loadings of escape and spirituality items are greater than 0.5 , are significantly different to zero at better than $1 \%$ and the two item collections satisfy the criterion of having Cronbach's $\alpha$ greater than 0.7 . This suggests convergent validity for these constructs (Anderson \& Gerbing, 1988; Hair, Black, Babin \& Anderson, 2010; Kolar \& Zabkar, 2010; Slavec \& Drnovšek, 2012; Yu et al., 2011). While the loadings of cultural adventure items are significantly different to zero, two loadings are smaller than 0.5, suggesting non-convergence (Hair et al., 2010; Slavec \& Drnovšek, 2012). Also, as reported above, Cronbach's $\alpha$ for cultural adventure is low in the generalisable sub-sample, again suggesting lack of convergence. In terms of discrimination, the covariances between factors are all significantly greater than zero at better than $1 \%$, but they are around 0.4 or smaller. As a check on this, following Kolar \& Zabkar (2010), the approach of Anderson and Gerbing (1988) was applied, in which pairs of latent factors were tested to see if their correlation might actually be one. These hypotheses were not supported for any pair, consistent with the factors having discriminant validity. Yet, finding a cross-loading from cultural adventure onto an escape item suggests that discrimination may not be as strong for cultural adventure. The cross-loading is less than 0.2 , which is small compared with the primary loading of the escape factor onto change of pace. However, the cross-loading should be retained (Matsunaga, 2010).

The results of this section are discussed more fully in the next section on implications for future research and management. Before moving to the discussion of results, the findings on motivations and spiritual attitude can be summarised as follows: To begin our rounds of PCA and CFA, we avoided the possibility of minor components arising and appearing to be prominent by using parsimonious approaches to determination of the number of constructs to extract and further in allowing only a small number of spirituality items into the analysis, as discussed in Section 3.2. Doing this still allowed spiritual attitude to emerge as important for the BFF audience. Next, we investigated the structure and consistency of the motivational and attitudinal constructs across samples. These were found to arise in holdout (our generalisable) samples under PCA and to be confirmed as latent factors using CFA, with some qualification on the generalisability of one motivational construct. In undertaking these steps in the analysis we have followed accepted practice throughout Sections 3 and 4 For reference see Basto and Pereira, 2012; Braun et al., 2012; Slavec and Drnovšek, 2012; Schmitt, 2011; Yu et al. 2011; Davidson et al. 2008; Brown 2006; Fabrigar et al. 1999; Kline 1994. That is, we have robustly established evidence in support of our objectives. 


\section{Conclusions and Implications}

\subsection{Theoretical implications and future research}

In summary, the BFF audience are characterised by young, highly educated and firsttime visitors. More than half of the respondents were not affiliated with formal religious practice. There is some evidence that the festival attracts pagans and wiccans, reflecting the spiritual roots of the festival. In common with other festival studies, the audience comprised a mixed range of visitors, including tourists, residents of Edinburgh, other Scottish residents and firsttime and repeat visitors. It is evident that residents and domestic visitors make up a sizeable proportion of the audience, but $30 \%$ of the audience are normally resident outside Scotland and this percentage rises to nearly $40 \%$ when temporary residents of Edinburgh are taken into account. Recall also the earlier finding of Gonzalez (2007:20) on visitors to BFF that "just under a third were tourists", suggesting a tourist component of the audience year on year. At other events and festivals, domestic visitors are a key market segment (Chang \& Yuan, 2011; Formica \& Uysal, 1996; Yuan, Cai, Morrison \& Linton, 2005) as is the local market (Nicholson \& Pearce, 2000), meaning in the current study Scottish residents including those who did not reside in Edinburgh. The presence of tourists and other travellers, notably international students in Scotland to study, indicates that potentially BFF has wide appeal as a component of Edinburgh's events calendar. Indeed, travellers residing beyond Edinburgh, both domestic and international, visited the city specifically for the festival. That this is the case is not unusual as local festivals are regularly used to promote tourism as well as to contribute to economic development (Felsenstein \& Fleischer, 2003). Edinburgh festivals and events serve economic development in that they make Scotland even more attractive as a destination (SQW Ltd/TNS Travel and Tourism 2005) for a variety of reasons including, as demonstrated in our BFF data, for those international travellers who arrive for periods of study, so helping to sustain Scotland's educational sector and the businesses that cater to the additional consumption that occurs (Richards and Palmer, 2010).

In the preceding sections it was shown that two motivations and one attitudinal construct had relevance in the context of the Beltane Fire Festival. The motivations mapped onto four "escape" items and three "cultural adventure" items. Escape reflects a desire to relieve stress and boredom and change routine aspects of life. Such a factor is reported in studies spanning 
the past twenty years (McDowall, 2010; Mohr et al., 1993; Uysal et al., 1993; Yolal et al., 2012). The factor cultural adventure includes items reflecting respondents' desire to enhance their cultural knowledge, attain a new experience and find adventure. Earlier studies identified the factor cultural exploration (Chang, 2006; Crompton \& McKay, 1997; Lee, 2000; Lee et al., 2004; Schofield \& Thompson, 2007), with which cultural adventure has similarities; however, in the current study it is labelled "cultural adventure" in order to capture the inclusion of the measured item "to seek adventure", which in other studies loads on another factor. While the two motivations have parallels in earlier research, the construct involving spiritual attitudes, encompassing interconnectedness and individuals being or becoming spiritual, appears to be little known. However, its emergence is consistent within the context of BFF and the SHE project outcomes.

Initially, we explored with PCA in one collection of datasets and found there was a role for two motivational factors to which the addition of a construct based on spiritual attitude was justified. Using PCA in generalisable or holdout datasets, this same structure persisted. To confirm the factor structure, CFA was performed in the holdout samples, with extremely good outcomes indicated by the values obtained for fit indices. As noted by Schreiber et al. (2006: 327 ) "in general, if the vast majority of the indexes indicate a good fit, then there is probably a good fit". Thus, on this basis we conclude that spiritual attitude figures as a factor for the BFF audience. As noted earlier, the objectives were to: identify motivations for attending the festival; trial questionnaire items on spirituality; and, assess whether spirituality might have a role in visitor intentions. With our approach, the first and third of these have been attained in that the spirituality and escape factors were extracted in PCAs and found to be valid constructs in CFA. In relation to the second, there are caveats on the instrument, not regarding spiritual-attitude items, but regarding the motivations arising from the covariation of escape-item errors, a motivation cross-loading, the weakening of discriminant validity for cultural adventure and the failure of that motivation to display convergent validity. Overall, on the second objective we can conclude that the trial of spiritual-attitude items was successful in providing evidence in support of the other study objectives, but in other respects, relating to motivations, the instrument might be refined for further application.

With regard to the correlation of errors in the escape items change of pace and relieve boredom two explanations are usually offered, as noted by Brown (2006). First, another latent 
factor, which was not included in the model, is responsible for a common part of the error variances. Conceivably, another aspect of spiritual attitude, not covered by our concentration on spiritual maturity, is responsible. Equally, some other construct may be responsible. However, having said this, it becomes a matter for further research as to the nature of the latent factor that might account for the error covariance. A second explanation is the presence of a method factor that is, a factor explaining variability to different methods of assessing constructs. Frequently, such a factor is thought to arise where combinations of negatively and positively stated items are used. The full items that have correlated errors were "I came to relieve boredom" and "I came for a change of pace from everyday life". It may be possible in the minds of the Beltane audience that the boredom item contains negative connotations that are reversed by the positive association of relieving boredom with a change of pace. This change of pace might be associated with the changing season, the possibility of the carnivalesque, the licentious nature of aspects of BFF, or the possibility of being spiritually uplifted. To assess if a method effect is involved, further investigation is required.

Next, consider the cross-loading of cultural adventure onto the item "change of pace" in the escape factor. There appears to be a consistency about this cross-loading. The reason being that cultural adventure is primarily associated with items about change in the form of increasing knowledge, new experience and seeking adventure. Whether such a cross-loading arises in CFAs generally is another area for further investigation. That this may be possible is demonstrated by a qualitative finding of Noy (2004) that backpackers speak of self-change and spirituality (see also Timothy \& Conover, 2006; Willson, 2011). On the other hand, as reported in Section 2, change of pace appears to have a diversity of potential interpretations, as it loads onto yet a different factor - socialisation and entertainment - in the work of Formica and Uysal (1998).

The CFA includes the correlations between the spiritual-attitude construct and motivations (for example, escape), which while small, are significantly different to zero. Similarly, there is a significant correlation between the motivational factors. Thus, to understand, for example, repeat attendance, a model might include paths linking motivations; but, in addition, there is evidence that either or both the linkages from motivation onto attitude and from attitude to motivation should be involved. For some commentators, motivation influences attitudes (Huang \& Hsu, 2009; Hsu et al., 2010; Nyaupane, Paris \& Teye, 2011) and for others it 
is the reverse, although explanations of the influence of attitudes on motivation are less frequent. Nonetheless, Gnoth's (1997) conceptual model suggests that motivation affects attitudes and that attitudes link back or feedback to motivation via expectations and effect. That attitudes influence motivation can be seen in other research, for example, Kotchen and Reiling (2000) and Luo and Deng (2008). Overall, the current research makes four contributions to tourism management. First, it contributes to the current body of knowledge about visitor motivations to attend unorthodox events as well as shedding light on visitors' spiritual attitudes. Second, in keeping with earlier work, this paper confirms the value of existing motivation scales and their applicability in this unorthodox context, although raising qualifications on their use. Third, it contributes to an understanding of the interplay between motivations and attitudes. Finally, this paper points to the value of undertaking empirical research in unusual environments to identify constructs which have not been noted previously. The current BFF research further raises the possibility of including attitudes in studies of motivation in the context of managing festivals and tourism.

With regard to future research, there are a variety of avenues to explore. From a methodological perspective, it would be useful to extend the approach undertaken in this study to other tourism management contexts. Specifically, a three step approach was undertaken comprising an exploratory analysis of principal components, conditioning with parallel analysis, very simple structure and minimum average partial correlation to arrive at the number of factors to seek. Thereafter, factors identified in the exploratory phase were then subjected to reexamination in other samples, one of which was the application of confirmatory factor analysis and, subsequently, a search for relevant cross loadings and factor correlations. Given the strength of the results, it is suggested the deployment of such re-testing in future studies will be valuable. Another avenue to investigate is the significance of spiritual attitudes to understanding visitors' decision-making processes. In light of our results, there is scope to investigate spiritual attitudes within a range of festivals and tourism experiences, including other unconventional experiences that travellers seek. With regard to festivals, there are a variety of contexts in which the significance of spiritual attitudes, as well as motives, can be explored, for example, preLenten carnivals as well as festivities operating in non-formal religious contexts and which may offer a transcendent experience to the audience. Another line of enquiry relates to the type of visitor and whether potential differences exist in terms of spiritual attitudes and motives. Commentators have previously identified differences between motivations for first-time and 
repeat visitors (Scott, 1996) and identifying differences or similarities in terms of spiritual attitudes would be equally fruitful in informing market segmentation.

\subsection{Managerial implications}

Major and mega events have long been recognised as a vehicle for destination branding and generating tourism revenue as well as contributing to the cultural and social vitality of a city. However, destinations require a balanced portfolio of events that contribute to tourism development. For as Getz (2012: 178) argued: "portfolios of events can be designed for maximum impact, especially to overcome seasonality of demand and appeal to multiple target segments". Major festivals held in Edinburgh are not only internationally renowned but have a significant economic impact, particularly given their role in attracting domestic and international visitors to the city (BOP Consulting, 2011). In recognition of the value of a balanced portfolio of events, the city has adopted a strategy which advocates this (City of Edinburgh Council, 2007) and, furthermore, a core objective of Edinburgh's tourism strategy is to achieve balance and reduce seasonality in the tourism sector (ETAG, 2012). The BFF is one event contributing to the cultural economy and tourism development. Managerial implications emanating from the current study of BFF relate to tourism development, balancing the portfolio, marketing strategies and repeat visitation, all of which impinge on developing the visitor market, particularly tourist visits.

In terms of contributing to further development of the tourism market and overcoming seasonality, the festival is at a strategic crossroads. In the last quarter of a century, the contemporary BFF has developed on an organic base from its grassroots origins with little in the way of external support. Although the festival occurs in a low for tourism to Edinburgh, takes place on a site with capacity constraints and is not extensively marketed, it attracts an audience of approximately 8500 , of which a sizeable proportion are tourists. This suggests there is not only a market for the festival but that there is potential to further expand its audience. This might be achieved with the judicious investment of funds by the City of Edinburgh in the development and marketing of Beltane. Such investment would be in line with Edinburgh's strategy to achieve balance and reduce seasonality, as the BFF occurs out of the main tourist season (ETAG, 2012). The experience in reviving the ancient Beltane festival further suggests there may be scope to expand provision of this type of event across the seasons drawing on some of the other seven important events in the pagan calendar that are rooted in ancient ritual. 
In general, the BFF can be characterised as self-reliant, independent of external sponsorship and maintaining a grassroots or community oriented ethos. Nevertheless, in order to meet changing health and safety requirements, the Beltane Fire Society (BFS) has professionalised to an extent. A possibility would be for BFS to professionalise further with the aim of augmenting the audience base and raising repeat attendance. This would require the BFS to broaden the appeal of the festival to the visitor market and address issues that may deter repeat visits. Broadening the audience base may involve greater dialogue with tourism and cultural policy makers to obtain funding to target marketing communication channels, so as to exploit our findings that spiritual attitudes were pertinent and the audience motivations of escape and cultural adventure had relevance. This could be in the form of promoting more widely the nature of the event, its deep-seated history in the broader European context, and how it might satisfy desires for cultural understanding, escape from the cares of everyday life, and attainment of transcendent experience. Also, it may be that specific aspects could be emphasised and developed in promotional material to capture more international and domestic tourists with interests in aspects of the festival, such as its origins in ancient Scottish history.

Further, a significant proportion of the audience knew little about the event (43.2\%) or heard about it informally (33.4\%). This again suggests marketing communications could be more focused on the nature of Beltane. In so doing, this could contribute to greater customer satisfaction, thereby encouraging repeat visits, as well as potentially garnering further visitors. As we reported earlier, the audience are characterised by young and highly educated visitors and in order to encourage and develop repeat visitation, appropriate marketing channels need to be sought and sustained, such as, social media as well as conventional communication channels. The Edinburgh BFF has unique features, such as occurring in the heart of the city, being the largest fire festival in Europe, being conducted in an English-speaking environment and reflecting the fecundity, licentiousness and content of rituals that previously were practised widely in Europe. As such, a more focused and targeted marketing strategy could assist in attracting a wider range of visitors and tourists.

The study results also indicate the majority of the audience are first time visitors $(80.4 \%)$. It is commonly perceived that, at an economic level, repeat visitors can be more beneficial compared to first-time visitors, although the evidence is mixed (Shani, Rivera \& Hara, 2009). Undoubtedly, repeat visitors are critical in ensuring festival sustainability as illustrated by 
Crompton and McKay (1997: p.426) who argued that "most festivals draw from a relatively local area, so their continued viability is likely to be dependent on a high level of repeat visitation". Hence, the lack of repeat visitation requires investigation. A variety of reasons could potentially explain non-repeat visits. First, the festival experience may be such that it induces a one-off visit but does not engender a sense of loyalty to return again. Second, although the proportion of first-time visitors is high it should be noted that there is a group who are unlikely to attend again because they are transient international students from as far afield as North America, who came to Edinburgh for reasons other than tourism or to visit BFF. Endeavouring to retain a substantial number of individual members of this particular group lacks feasibility. However, it is arguable that even though they might not attend again, a focussed marketing strategy might attract even more first-time visitors of this type. Also, it is possible that such itinerant residents might return to their home countries and suggest that studying in Edinburgh has advantages, beyond the quality of education and the benefits of the city, which are associated with a diversity of festival experiences. This would have positive ramifications for private-sector business growth and expansion of educational services. Finally, there may be a relationship between visitors being dissatisfied with the festival and choosing not to attend again. Understanding satisfaction and dissatisfaction among the majority of non-returners, would inform future development and customer retention strategies.

\section{References}

Ajzen, I. (2005). Attitudes, Personality and Behavior, New York: Open University Press

Ajzen, I. \& Fishbein, M. (2000). Attitudes and the attitude-behavior relation: reasoned and automatic processes, European Review of Social Psychology, 11, 1-33

Anderson, J., \& Gerbing, D. (1988). Structural equation modelling in practice: a review and recommended two-step approach, Psychological Bulletin, 103, 411-423.

Ashley, P. (2007). Towards an understanding and definition of wilderness spirituality. Australian Geographer, 38, 53-69.

Astin, A. W., Astin, H. A., \& Lindholm, J. A. (2011). Assessing students' spiritual and religious qualities. Journal of College Student Development, 52, 39-61

Astin, A. W. \& Keen, J. P. (2006). Equanimity and spirituality. Religion and Education, 33, 1-8. Backman, K. F., Backman, S. J. , Uysal, M., \& Sunshine, K. M. (1995). Event tourism: an examination of motivations and activities. Festival Management and Event Tourism, 3, 15-24. Bakhtin, M. (1984). Rabelais and his world. Bloomington: Indiana University Press. (trans. 
Hélène Iswolsky).

Basto, M., \& Pereira, J. (2012). An SPSS R-Menu for ordinal factor analysis. Journal of Statistical Software, 46, 1-29.

Bedeian, A., Armenakis, A. and Randolph, W. (1988). The significance of congruence coefficients: a comment and statistical test. Journal of Management, 14(4), 559-566.

BFS (Beltane Fire Society). (2012). The reds. http://beltane.org/about/reds/ (Accessed: 24 November 2012).

BFS (Beltane Fire Society) (2011). A Detailed History of Beltane.

http://beltanefiresociety.wordpress.com/a-detailed-history-of-beltane/. (Accessed: 19 December 2013)

BFS (Beltane Fire Society). (2007). Beltane. http://staging.beltane.org/festivals/beltane (Accessed: 8 December 2012).

Blackwell, M., Honaker, J., \& King, G. (2012). Multiple overimputation: a unified approach to measurement error and missing data. http://gking.harvard.edu/publications/multipleoverimputation-unified-approach-measurement-error-and-missing-data (Accessed: 21 October 2012).

BOP Consulting. (2011). Edinburgh festivals impact study. BOP Consulting.

Bowen, H. E., \& Daniels, M. J. (2005). Does the music matter? Motivations for attending a music festival. Event Management, 9, 155-164.

Braun, E., Woodley, A., Richardson, J. T. E and Leidner, B. (2012). Self-rated competences questionnaires from a design perspective. Educational Research Review, 7(1), 1-18

Brown, T. (2006). Confirmatory factor analysis for applied research. New York: Guildford Press. Bryant, A. N. (2007). Gender differences in spiritual development during the college years. Sex Roles, 56, 835-846.

Bryant, A. N., \& Astin, H. A. (2008). The correlates of spiritual struggle during the college years. Journal of Higher Education, 79, 1-27.

Chang, J. (2006). Segmenting tourists to Aboriginal cultural festivals: an example in the Rukai Tribal Area, Taiwan. Tourism Management, 27, 1224-1234.

Chang, R. C. Y., Kiela, J. \& Mak, A. H. N. (2010). Food preferences of Chinese tourists. Annals of Tourism Research, 37, 989-1011.

Chang, W., \& Yuan, J. (2011). A taste of tourism: visitors' motivations to attend a food festival. Event Management, 15, 13-23.

City of Edinburgh Council. (2007). Inspiring events strategy. Edinburgh: City of Edinburgh 
Council.

Cohen, E. (1998). Tourism and religion: a comparative perspective. Pacific Tourism Review, 2, $1-10$.

Cohen, E. (1979). A Phenomenology of Tourist Experiences. Sociology, 13, 179-201.

Collins-Kreiner, N. (2010). Researching pilgrimage: continuity and transformations. Annals of Tourism Research, 37, 440-456.

Crompton, J. L., \& McKay, S. L. (1997). Motives of visitors attending festival events. Annals of Tourism Research, 24, 425-439.

Dames, M (1992). Mythical Ireland. London: Thames and Hudson.

Damitz, M., Manzey, D., Kleinman, M. and Severin, K. (2003) Assessment center for pilot selection: construct and criterion validity and the impact of assessor type, Applied Psychology, 52, $193-212$.

Davidson, M. A., Tripp D. A., Fabrigar, L. R. and Davidson P. R. (2008). Chronic pain assessment: a seven-factor model. Pain Research and Management, 13, 299-308 de Mooij, M. (2010). Consumer Behavior and Culture: Consequences for Global Marketing and Advertising. London: SAGE

Dewar, K., Meyer, D., \& Li, W. M. (2001). Harbin, lanterns of ice, sculptures of snow. Tourism Management, 22, 523-532.

Digance, J. (2003). Pilgrimage at contested sites. Annals of Tourism Research, 30, 143-159. Dinno, A. (2011). Package ‘Paran’ Version 1.4.3, http://cran.r-project.org/ (Accessed: 21 October 2012).

Elkins, D. N., Hedstrom, L. J., Hughes, L. L., Leaf, J. A., \& Saunders, C. (1988). Toward a humanistic-phenomenological spirituality: definition, description, and measurement. Journal of Humanistic Psychology, 28, 5-18.

ETAG (Edinburgh Tourism Action Group). (2012). Edinburgh 2020: The Edinburgh Tourism Strategy. Edinburgh: ETAG.

Evans, C., Connell, J., Barkham, M., Margison, F., McGrath, G., Mellor-Clark, J. \& Audin, K. (2002). Towards a standardised brief outcome measure: psychometric properties and utility of the CORE-OM, British Journal of Psychiatry, 180, 51-60.

Fabrigar, L., Wegener, D., MacCallum, R., \& Strahan, E. (1999). Evaluating the use of exploratory factor analysis in psychological research. Psychological Methods, 4, 272-299. Faulkner, B., Fredline, E., Larson, M., \& Tomljenovic, R. (1999). A marketing analysis of Sweden's Storsjöyran musical festival. Tourism Analysis, 4, 157-171. 
Felsenstein, D. \& Fleischer, A. (2003). Local festivals and tourism promotion: the role of public assistance and visitor expenditure. Journal of Travel Research, 41, 385-392.

Festivals Edinburgh. (2013). Edinburgh's Festivals: Defining Scotland's Cultural Identity on the Global Stage. Edinburgh: Festivals Edinburgh.

Field, A. (2009). Discovering statistics using SPSS. Los Angeles: Sage.

Fleischer, A. (2000). The tourist behind the pilgrim in the Holy Land. International Journal of Hospitality Management, 19, 311-326.

Formica, S., \& Uysal, M. (1998). Market segmentation of an international cultural-historical event in Italy. Journal of Travel Research, 36, 16-24.

Formica, S., \& Uysal, M. (1996). A market segmentation of festival visitors: Umbria jazz festival in Italy. Festival Management and Event Tourism, 3, 175-182.

Frazer, J. (1922). The golden bough: a study in magic and religion. New York: Macmillan. Frazer, J. with Fraser, R (1998). The golden bough: a study in magic and religion, Oxford: Oxford University Press.

Frey, N., \& George, R. (2010). Responsible tourism management: the missing link between business owners' attitudes and behaviour in the Cape Town tourism industry. Tourism Management, 31, 621-628.

Gallarza, M. G., Arteaga, F., Floristán, E., \& Gil, I. (2009). Consumer behavior in a religious event experience: an empirical assessment of value dimensionality among volunteers. International Journal of Culture, Tourism and Hospitality Research, 3, 165-180.

Gau, J. (2011) The convergent and discriminant validity of procedural justice and police legitimacy: an empirical test of core theoretical propositions. Journal of Criminal Justice, 39, 489-498.

Getz, D. (2012). Event studies: discourses and future directions. Event Management, 16, 171187.

Getz, D. (2008). Event tourism: definition, evolution, and research. Tourism Management, 29, 403-428.

Gnoth, J. (1997). Tourism motivation and expectation formation. Annals of Tourism Research, 24, 283-304.

Gonzalez, R. (2007). Beltane Fire Festival: inaugural economic impact and audience profile assessment. Edinburgh: Beltane Fire Festival.

Graburn, N. (2001). Secular ritual: a general theory of tourism. In V. Smith, \& M. 
Brent (Eds.), Hosts and guests revisited: tourism issues of the 21st century (pp. 42-50). New York: Cognizant Communication Corporation.

Graburn, N. H. H. (1989). Tourism: the sacred journey. In V.L. Smith (Ed.), Hosts and guests: the anthropology of tourism (pp. 21-36). Philadelphia: University of Pennsylvania Press. Gursoy, D., Spangenberg, E. R., \& Rutherford, D. G. (2006). The hedonic and utilitarian dimensions of attendees' attitudes toward festivals. Journal of Hospitality and Tourism Research, 30, 279-294.

Gyimóthy, S. (2009). Casual observers, connoisseurs and experimentalists: a conceptual exploration of niche festival visitors. Scandinavian Journal of Hospitality and Tourism, 9, 177 205.

Hair, J., Black, W., Babin, B., \& Anderson, R. (2010). Multivariate data analysis: a global perspective. Upper Saddle River: Pearson.

Harrington, D. (2008). Confirmatory factor analysis. Online: Oxford Scholarship Hayton, J., Allen, D., \& Scarpello, V. (2004). Factor retention decisions in exploratory factor analysis: a tutorial on parallel analysis. Organisation Research Methods, 7, 191-2005.

Hill, P. C. Pargament, K., Hood, R., W., McCullough, M. E., Swyers, J. P., Larson, D. B. and Zinnbauer, B.J. (2000). Conceptualising religion and spirituality: points of commonality, points of departure. Journal for the Theory of Social Behaviour, 30, 51-77.

Hooper, D., Coughlan, J., \& Mullen, M. (2008) Structural equation modelling: guidelines for determining model fit." The Electronic Journal of Business Research Methods, 6, 53-60.

www.ejbrm.com, (Accessed: 09 June 2013).

Hsu, C., Cai, L. A., \& Li, M. (2010) Expectation, motivation and attitude: a tourist behavioural model, Journal of Travel Research, 49, 282-296.

Huang, S., \& Hsu, C. H. C. (2009). Effects of travel motivation, past experience, perceived constraint, and attitude on revisit intention. Journal of Travel Research, 48, 29-44.

Jordan, A. (2001) College student cheating: the role of motivation, perceived norms, attitudes and knowledge of institutional policy, Ethics and Behavior, 11, 233-247.

Kaiser, H. (1970). A second generation Little Jiffy. Psychometrika, 35, 401-415.

Kale, S. (2004). Spirituality, religion, and globalization. Journal of Macromarketing, 24, 92-107. King, G., Honaker, J., Joseph, A., \& Scheve, K. (2001). Analyzing incomplete political science data: an alternative algorithm for multiple imputation. American Political Science Review, 95, 4969.

Kline, P. (1994). An easy guide to factor analysis, London: Routledge. 
Kolar, T. \& Zabkar, V. (2010). A consumer-based model of authenticity: an oxymoron or the foundation of cultural heritage marketing? Tourism Management, 31, 652-664.

Kotchen, M., \& Reiling, S. (2000). Environmental attitudes, motivations and contingent valuation of nonuse values: a case study involving endangered species. Ecological Economics, 32, 93107.

Kumar, S. (2000). Reverential ecology. Kyoto Journal, 43, 46-58.

Lam, T., \& Hsu, C.H.C. (2006). Predicting behavioural intention of choosing a travel destination. Tourism Management, 27, 589-599.

Lam, T., \& Hsu, C.H.C. (2004). Theory of planned behaviour: potential travelers from China. Journal of Hospitality and Tourism Research. 28, 463-482.

Lee, C-K. (2000). A comparative study of Caucasian and Asian visitors to a Cultural Expo in an Asian setting. Tourism Management, 21, 169-176.

Lee, T. H. (2009). A structural model to examine how destination, image, attitude, and motivation affect the future behaviour of tourists. Leisure Sciences, 31, 215-236.

Lee, J., \& Beeler, C. (2009). An investigation of predictors of satisfaction and future intention: links to motivation, involvement, and service quality in a local festival. Event Management, 13, 17-29.

Lee, C-K., Lee, Y-K., \& Wicks, B. E. (2004). Segmentation of festival motivation by nationality and satisfaction. Tourism Management, 25, 61-70.

Lepp, A. (2007). Residents' attitudes towards tourism in Bigodi village, Uganda. Tourism Management, 28, 876-885.

Li, M., Huang, Z., \& Cai, L. A. (2009). Benefit segmentation of visitors to a rural communitybased festival. Journal of Travel and Tourism Marketing, 26, 585-598.

Li, X. R., \& Petrick, J. F. (2006). A review of festival and event motivation studies. Event Management, 9, 239-245.

Lindholm, J. A. \& Astin, H. S. (2008). Spirituality and pedagogy: faculty's spirituality and use of student-centered approaches to undergraduate teaching. Review of Higher Education, 31, 185207.

Livingstone, S. (2000). Scottish customs. Edinburgh: Birlinn.

Love, P. and Talbot, D. (2005). Defining spiritual development: a missing consideration for student affairs. In E. Wilson, \& L. Wolf-Wendel (Eds.), ASHE Reader on college student development theory Boston: Custom Publishing. 
Luo, Y., \& Deng, J. (2008). The new environmental paradigm and nature-based tourism motivation. Journal of Travel Research, 46, 392-402.

Mannel, R., \& Iso-Ahola, S. (1987). Psychological nature of leisure and tourism experiences. Annals of Tourism Research, 14, 314-329.

Manson, B. (2006). An examination of Samhain and Beltane rituals in contemporary pagan practice. Montreal: University of Concordia.

Manzo, L. C. (2003). Beyond house and heaven: toward a revisioning of emotional relationships with places. Journal of Environmental Psychology, 23, 47-61.

Matheson, C. M. and Tinsley, R. (2010). Carnivalesque in the face of external pressures: a case study of the Beltane Fire Festival, ATLAS annual conference and colloquium 2010: mass tourism versus niche tourism, Limassol, Cyprus, November 3-5.

Matsunaga, N. (2010). How to factor-analyze your data right: do's, don'ts and how-to's, International Journal of Psychological Research, 3, 97-110.

McDowall, S. (2010). A comparison between Thai residents and non-residents in their motivations, performance evaluations, and overall satisfaction with a domestic festival. Journal of Vacation Marketing, 16, 217-233.

Misetic, A., \& Sabotic, I. (2006). 'Days of Radunica': a street festival in the Croatian town of Split. In D. Picard, \& M. Robinson (Eds.), Festivals, tourism and social change: remaking worlds (pp. 119-132). Clevedon: Channel View Publications.

Mohamad, A., Lo, M-C., Songan, P., \& Yeo, A. (2012). Dimensionality of communities belief attitude toward rural tourism development, British Journal of Arts and Social Sciences, 6, 245254.

Mohr, K., Backman, K. F., Gahan, L. W., \& Backman, S. J. (1993). An investigation of festival motivations and event satisfaction by visitor type. Festival Management and Event Tourism, 1, 89-97.

Murray, M., \& Graham, B. (1997). Exploring the dialectics of route-based tourism: the Camino de Santiago. Tourism Management, 18, 513-524.

Nako, Z., \& Barnard, A. (2012). Construct validity of competency dimensions in a leadership assessment and development centre. African Journal of Business Management, 6, 9730-9737. Nicholson, R. E., \& Pearce, D. G. (2001). Why do people attend events: a comparative analysis of visitor motivations at Four South Island events. Journal of Travel Research, 39, 449-460. Nicholson, R., \& Pearce, D. G. (2000). Who goes to events: a comparative analysis of the profile characteristics of visitors to four South Island events in New Zealand. Journal of Travel 
Marketing, 6, 236-253.

Nolan, M. L., \& Nolan, S. (1992). Religious sites as tourism attractions in Europe. Annals of Tourism Research, 19, 68-78.

Noy, C. (2004). This trip really changed me: backpackers' narratives of self-change. Annals of Tourism Research, 31, 78-102.

Nyaupane, G. P., Paris, C. M., \& Teye, V. (2011). Study abroad motivations, destination selection and pre-trip attitude formation. International Journal of Tourism Research, 13, 205217.

Olsen, D. H., \& Timothy, D. J. (2006). Tourism and religious journeys. In D. J. Timothy, \& D. H. Olsen (Eds.), Tourism, religion and spiritual journeys (pp. 1-21). London and New York: Routledge.

Park, K-S,. Reisinger, Y., \& Kang, H-J. (2008). Visitors' motivations for attending the South Beach Wine and Food Festival, Miami Beach, Florida. Journal of Travel and Tourism Marketing, 25, 161-181.

Partridge, C. (2006). The spiritual and the revolutionary: alternative spirituality, British free festivals and the emergence of rave culture. Culture and Religion, 7, 41-60.

Perera, P. and Vlosky, R. (2013). How previous visits shape trip quality, perceived value, satisfaction and future behavioural intentions: the case of forest-based ecotourism in Sri Lanka, International Journal of Sport Management, Recreation and Tourism, 11, 1-24.

Preacher, K. J., \& Coffman, D. L. (2006). Computing power and minimum sample size for RMSEA [Computer software]. http://quantpsy.org/. (Accessed: 11 December 2012).

Principe, W. (1983). Toward defining spirituality. Studies in Religion,12, 127-41.

Quinn. B. (2010). Arts festivals, urban tourism and cultural policy. Journal of Policy Research in Tourism, Leisure and Events, 2, 264-279.

Quinn, B. (2007). Arts festivals and the city. In: R. Paddison \& S. Miles (Eds.) Culture-Led Urban Regeneration (85-101). London: Routledge.

Raybould, M., Digance, J., \& McCullough, C. (1999). Fire and festival: authenticity and visitor motivation at an Australian folk festival. Pacific Tourism Review, 3, 201-212.

Reid, G. (2006). The politics of city imaging: a case study of the Edinburgh MTV Europe Music Awards 03. Event Management, 10, 35-46.

Reimers, A., Jekauc, D., Mess, F., Mewes, N.; \& Woll, A. (2012). Validity and reliability of a selfreport instrument to assess social support and physical environment correlates of physical activity in adolescents, BMC Public Health, 12, www.biomediccentral.com/1471-2458/12/705 
(Accessed: 07 May 2013).

Revelle, W., \& Rocklin T. (1979). Very simple structure - alternative procedure for estimating the optimal number of interpretable factors. Multivariate Behavioral Research, 14, 403-414. Richards, G., \& Palmer, R. (2010). Eventful Cities: Cultural Management and Urban Revitalisation. Oxford: Elsevier.

Richards, G., \& Wilson, J. (2004). The impact of cultural events on city image: Rotterdam, Cultural Capital of Europe 2001. Urban Studies, 41, 1931-1951.

Rinschede, G. (1992). Forms of religious tourism. Annals of Tourism Research, 19, 51-67. Schiffman, L. G. \& Kanuk (2010). Consumer Behaviour. 10 $0^{\text {th }}$ ed. Upper Saddle River, NJ: Prentice Hall.

Schmitt, T. (2011). Current methodological considerations in exploratory and confirmatory factor analysis. Journal of Psychological Assessment, 29, 304-321.

Schneider, I. E., \& Backman, S. J. (1996). Cross-cultural equivalence of festival motivations: a study in Jordan. Festival Management and Event Tourism, 4, 139-144.

Schofield, K., \& Thompson, K. (2007). Visitor motivation, satisfaction and behavioural intention: the 2005 Naadam Festival, Ulaanbaatar. International Journal of Tourism Research, 9, 329-344. Schreiber, J., Stage, F., King, J., Nora, A., \& Barlow, E. (2006). Reporting structural equation modelling and confirmatory factor analysis results: a review. Journal of Educational

Research,99, 323-337.

Scott, D. (1996). A comparison of visitors' motivations to attend three urban festivals. Festival Management and Event Tourism, 3, 121-128.

Shani, A.. Rivera, M. A., \& Hara, T. (2009). Assessing the viability of repeat visitors to cultural Events: Evidence from the Zora! Festival. Journal of Convention and Event Tourism, 10, 89104.

Sharpley, R., \& Jepson, D. (2011). Rural tourism: a spiritual experience?. Annals of Tourism Research, 38, 52-71.

Sherry, J. F., \& Kozinets, R. V. (2007). Comedy of the commons: nomadic spirituality and the Burning Man festival. In R. W. Belk, \& J. F. Sherry (Eds.), Research in consumer behavior, vol.11: consumer culture theory (pp. 119-147). Oxford: Elsevier.

Shuo, Y., Ryan, C., \& Liu, G. (2009). Taoism, temples and tourists: the case of Mazu pilgrimage tourism. Tourism Management, 30, 581-588.

Slavec, A., \& Drnovšek, M. (2012). A perspective on scale development in entrepreneurship research, Economic and Business Review, 14, 39-62. 
Sparks, B. (2007). Planning a wine tourism vacation? Factors that help to predict tourist behavioural intentions. Tourism Management, 28, 1180-1192.

Spirituality in Higher Education (2004) Appendix A: College students' beliefs and values (CSBV) survey methodology http://spirituality.ucla.edu/docs/reports/Spiritual Life College Students Full Report.pdf (Accessed: 04 May 2013).

SQW Ltd/TNS Travel and Tourism (2005). Edinburgh's Year Round Festivals 2005-2005, Economic Impact Study.

Thompson, K., \& Schofield, P. (2009). Segmenting and profiling visitors to the Ulaanbaatar Naadam festival by motivation. Event Management, 13, 1-15.

Timothy, D. J., \& Conover, P. J. (2006). Nature religion, self-spirituality and new age tourism. In D. J. Timothy, \& D. H. Olsen (Eds.), Tourism, religion and spiritual journeys (pp. 139-155). Abingdon: Routledge.

Titmuss, C. (2000). Practicing with passion. In S. Kaza, \& K. Kraft (Eds.) Dharma rain: sources of Buddhist environmentalism (pp. 257-60). Boston: Shambhala.

Uysal, M., Gahan, L., \& Martin, B. (1993). An examination of event motivations: a case study. Festival Management and Event Tourism, 1, 5-10.

Van Gennep, A. (1960). The rites of passage. Chicago: The University of Chicago Press. Van Zyl, C., \& Botha, C. (2004). Motivational factors of local residents to attend the Aardklop national arts festival. Event Management, 8, 213-222.

Vargas-Sánchez, A., Porras-Bueno, N., \& Plaza-Mejía, M. (2011). Explaining residents' attitudes to tourism: is a universal model possible? Annals of Tourism Research, 38, 460-480. VisitScotland (n.d.) Scotland: the key facts on tourism in 2011.

http://www.visitscotland.org/pdf/VS Insights Key Facts 2012 Final.pdf. (Accessed: 02 October 2013)

Vukonić, B. (1992). Medjugorje's religion and tourism connection. Annals of Tourism Research, 19, 79-91.

Willson, G. B. (2011). The search for inner peace: considering the spiritual movement in tourism. The Journal of Tourism and Peace Research, 1, 16-26.

WTO (World Tourism Organisation UNWTO) (n.d.). Understanding Tourism: Basic Glossary. http://media.unwto.org/content/understanding-tourism-basic-glossary. (Accessed: 18 December 2013). 
Yolal, M., Çetinel, F., \& Uysal, M. (2009). An examination of festival motivation and perceived benefits relationship: Eskişehir international festival. Journal of Convention and Event Tourism, 10, 276-291.

Yolal, M., Woo, E., Çetinel, F., \& Uysal, M. (2012). Comparative research of motivations across different festival products. International Journal of Event and Festival Management, 3, 66-80. Yu, C-P., Chancellor, H., \& Cole, S. (2011). Measuring residents' attitudes toward sustainable tourism: a re-examination of the sustainable tourism attitude scale. Journal of Travel Research, 50, 57-63.

Yuan, J. J., Cai, L. A., Morrison, A. M., \& Linton, S. (2005). An analysis of wine festival attendees' motivations: a synergy of wine, travel and special events. Journal of Vacation Marketing, 11, 41-58.

Zhou, Q., Zhang, J., \& Edelheim, J. (2013). Rethinking traditional Chinese culture: a consumerbased model regarding the authenticity of Chinese calligraphic landscape. Tourism Management, 36, 99-112.

Zinnbauer, B., Pargament, K., \& Scott, A. (1999). The emerging meanings of religiousness and spirituality: Problems and prospects. Journal of Personality, 67, 889-919. 


\section{LIST OF FIGURE AND TABLE CAPTIONS}

Figure 1

Caption: Beltane Fire Festival Performance

Filename: Fig1Performance.tiff

Figure 2

Caption: The May Queen

Filename: Fig2MayQueen.tiff

Figure 3

Caption: The Analytical Approach

Filename: Fig3TheAnalyaticalApproach.docx

Figure 4

Caption: Figure 4 Patterns of correlations $(\times 100)$ in the first of the exploratory sub-samples

Filename: Fig4PatternsofCorrelationsExploratory.docx

Caption: Figure 5 Patterns of correlations $(\times 100)$ in the first of the confirmatory sub-samples Filename: Fig5PatternsofCorrelationsConfirmatory.docx

Table 1a

Caption: Table 1a Percentage distribution of characteristics

Filename: Table1aPercentagedistributionofcharacteristics

Table $1 \mathrm{~b}$

Caption: Table $1 \mathrm{~b}$ Summary responses to motivation and spirituality statements

Filename: Table1bSummaryresponses to motivationandspirirtualitystatements

Table 2

Caption: Table 2 Number of principal components to extract

Filename: Table2Numberofprincipalcomponentstoextract

Table 3

Caption: Table 3 Average values for PCA over exploratory sub-samples

Filename: Table3Averagevaluesoverexploratorysub-samplesofsize176

Table 4

Caption: Table 4 Average values for PCA over generalisable sub-samples

Filename: Table4Averagesovergeneralisablesub-samplesofsize199

Table 5

Caption: Table 5 CFA results in the first generalisable sub-sample

Filename: Table5CFAresultsinthefirstgeneralisablesub-sample 


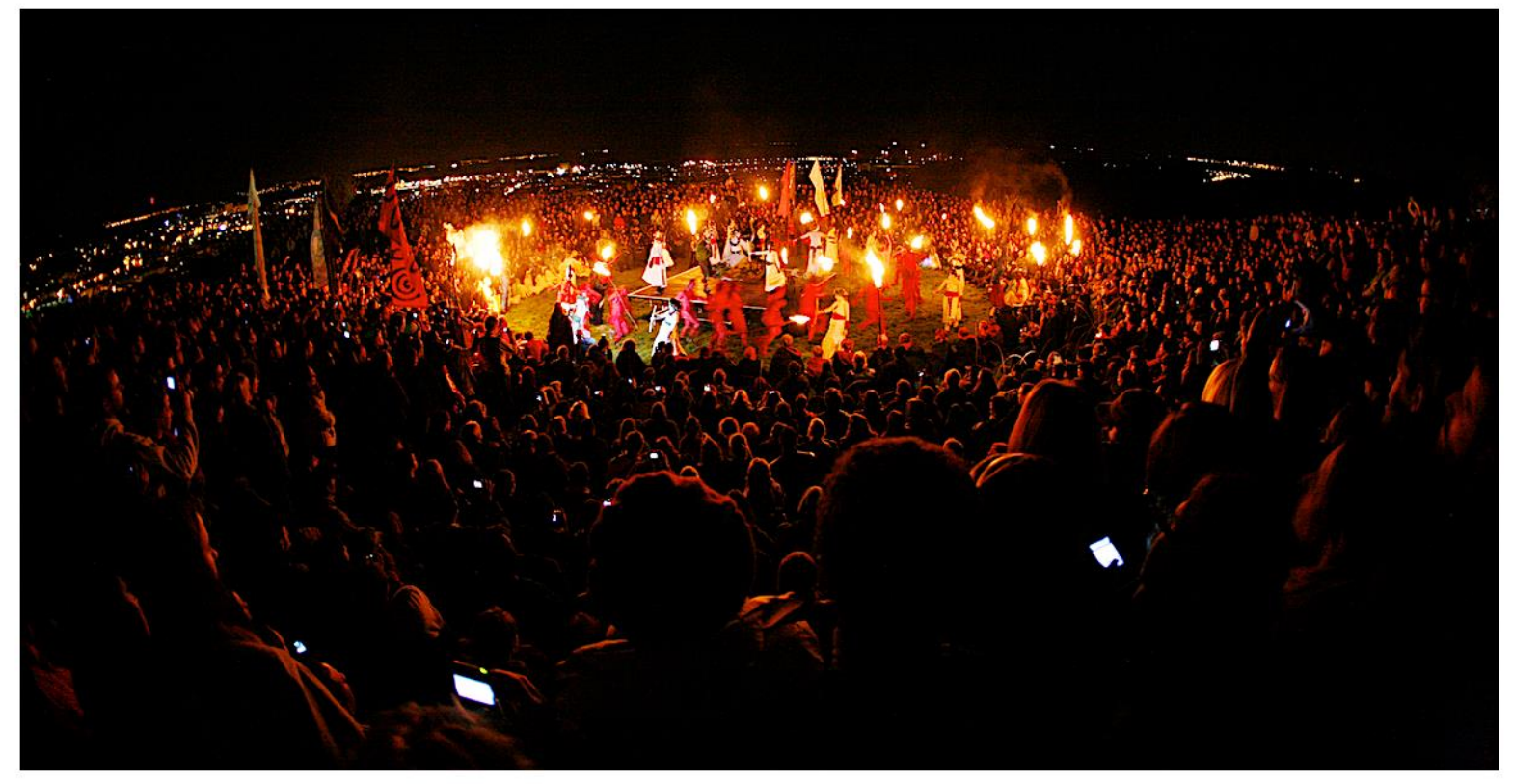

Figure 1 Beltane Fire Festival performance 


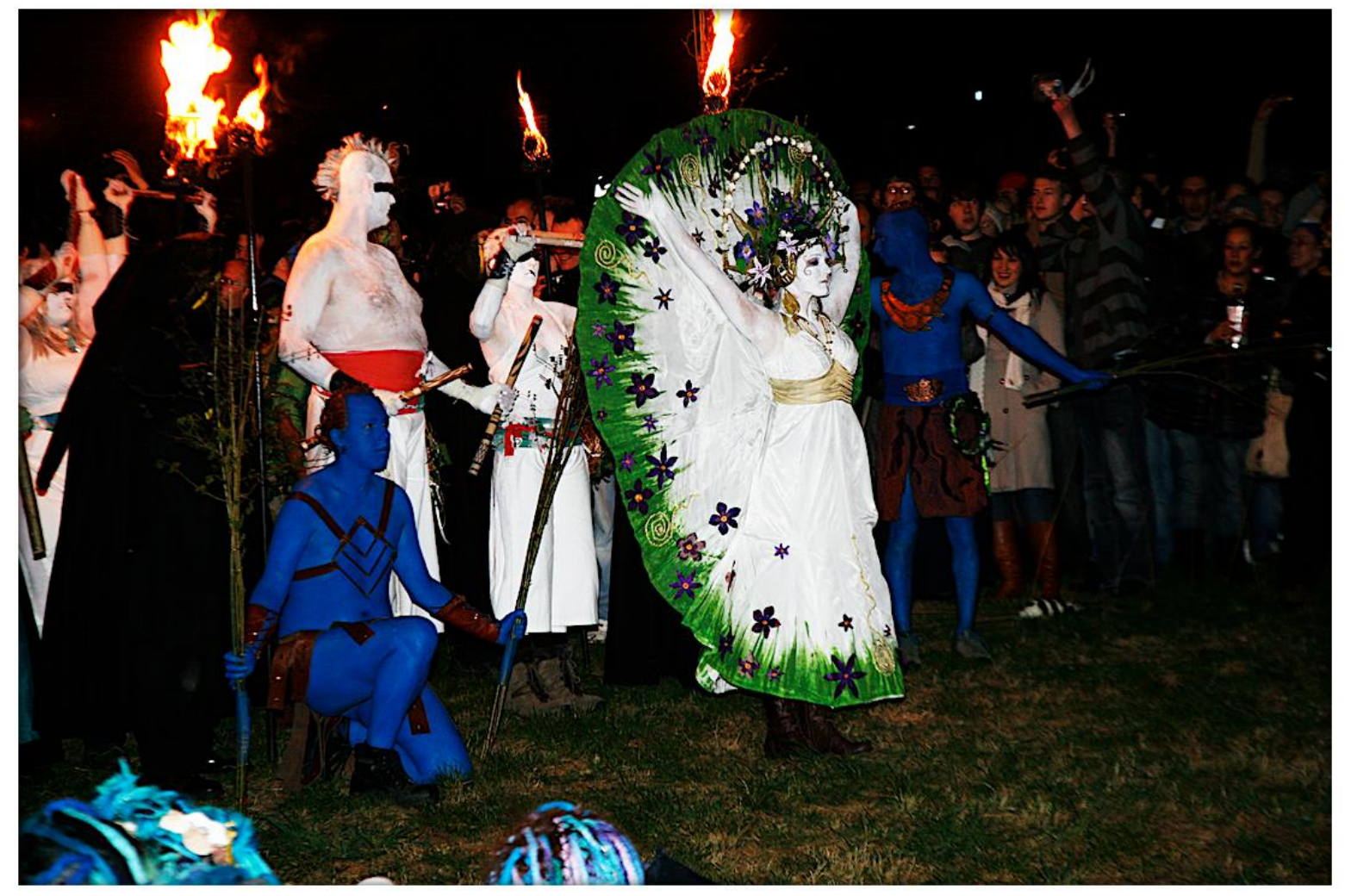

Figure 2 The May Queen 


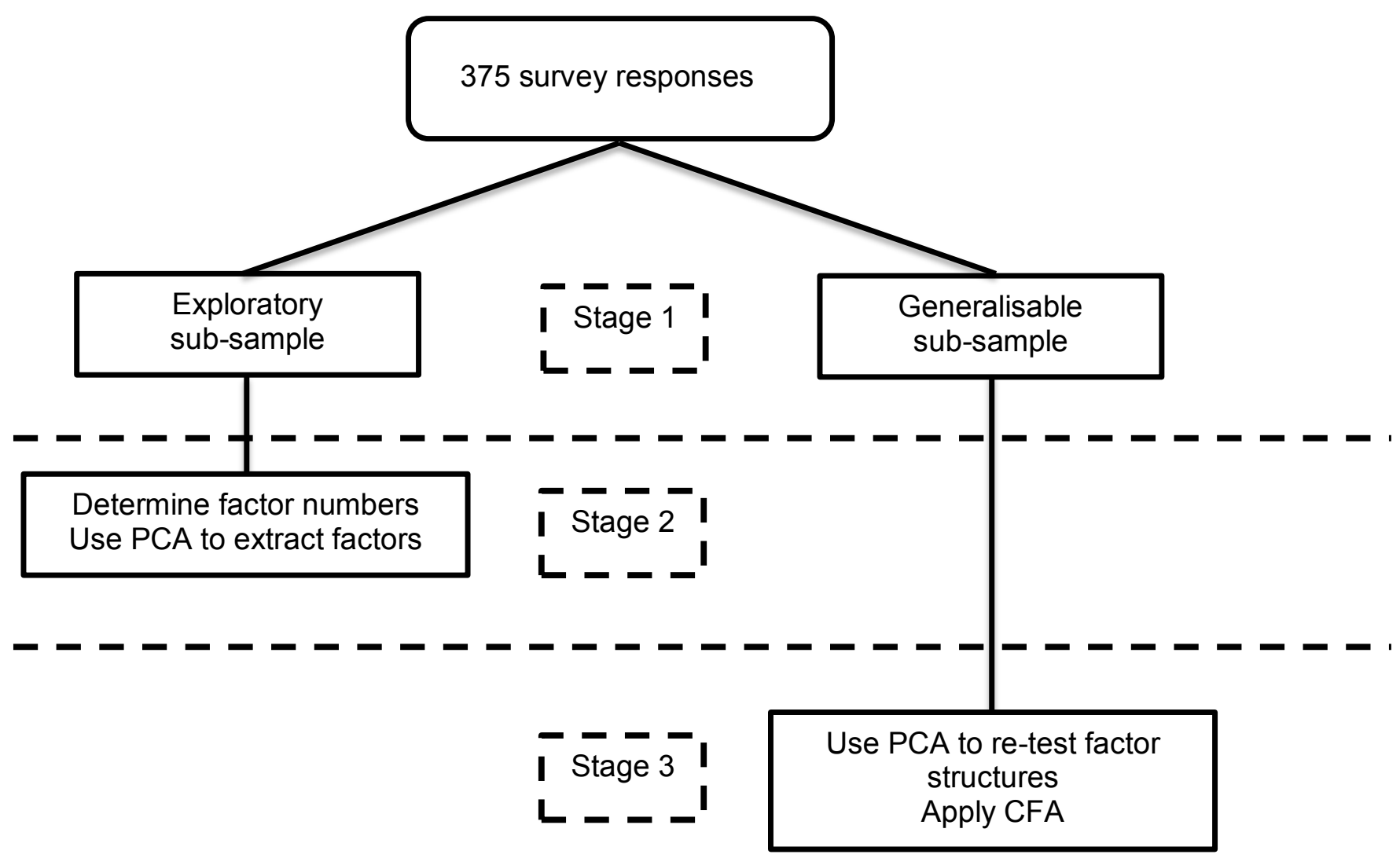

Figure 3 The analytical approach 


\begin{tabular}{|c|c|c|c|c|c|c|c|c|c|c|}
\hline & 1. & 2. & 3. & 4. & 5. & 6. & 7. & 9. & 10. & 11. \\
\hline 1. Escape routine & 100 & 88 & 75 & 71 & 24 & 29 & 34 & 10 & -2 & 8 \\
\hline $\begin{array}{l}\text { 2. Change of } \\
\text { pace }\end{array}$ & 88 & 100 & 68 & 60 & 22 & 28 & 27 & 16 & -8 & 8 \\
\hline 3. Relieve stress & 75 & 68 & 100 & 64 & 22 & 33 & 29 & 4 & -5 & 16 \\
\hline $\begin{array}{l}\text { 4. Relieve } \\
\text { boredom }\end{array}$ & 71 & 60 & 64 & 100 & 20 & 15 & 25 & 2 & -6 & 4 \\
\hline $\begin{array}{l}\text { 5. Increase } \\
\text { cultural }\end{array}$ & 24 & 22 & 22 & 20 & 100 & 64 & 61 & 24 & 4 & 29 \\
\hline $\begin{array}{l}\text { 6. New } \\
\text { experience }\end{array}$ & 29 & 28 & 33 & 15 & 64 & 100 & 66 & 16 & 12 & 16 \\
\hline $\begin{array}{l}\text { 7. Seek } \\
\text { adventure }\end{array}$ & 34 & 27 & 29 & 25 & 61 & 66 & 100 & 13 & 11 & 24 \\
\hline 9. Interconnected & 10 & 16 & 4 & 2 & 24 & 16 & 13 & 100 & 60 & 68 \\
\hline $\begin{array}{l}\text { 10. Grow } \\
\text { spiritually }\end{array}$ & -2 & -8 & -5 & -6 & 4 & 12 & 11 & 60 & 100 & 53 \\
\hline $\begin{array}{l}\text { 11. All spiritual } \\
\text { beings }\end{array}$ & 8 & 8 & 16 & 4 & 29 & 16 & 24 & 68 & 53 & 100 \\
\hline
\end{tabular}

Shading key for correlations

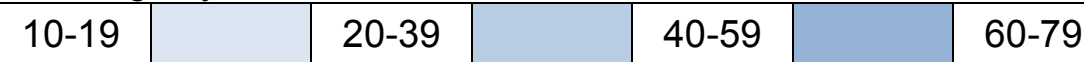

Figure 4 Patterns of correlations $(\times 100)$ in the first of the exploratory sub-samples 


\begin{tabular}{|l|c|c|c|c|c|c|c|c|c|c|}
\hline & $\mathbf{1 .}$ & $\mathbf{2 .}$ & $\mathbf{3 .}$ & 4. & $\mathbf{5 .}$ & $\mathbf{6 .}$ & $\mathbf{7}$ & $\mathbf{9 .}$ & $\mathbf{1 0 .}$ & $\mathbf{1 1 .}$ \\
\hline & 100 & 72 & 60 & 67 & 17 & 10 & 19 & 14 & 4 & 10 \\
\hline 1. Escape routine & 72 & 100 & 52 & 43 & 28 & 23 & 27 & 24 & 18 & 14 \\
\hline $\begin{array}{l}\text { 2. Change of } \\
\text { pace }\end{array}$ & 60 & 52 & 100 & 48 & 11 & -3 & 7 & 19 & 12 & 23 \\
\hline 3. Relieve stress & 67 & 43 & 48 & 100 & 22 & -2 & 27 & 14 & -2 & 3 \\
\hline $\begin{array}{l}\text { 4. Relieve } \\
\text { boredom }\end{array}$ & 17 & 28 & 11 & 22 & 100 & 45 & 31 & 19 & 23 & 32 \\
\hline $\begin{array}{l}\text { 5. Increase } \\
\text { cultural }\end{array}$ & 10 & 23 & -3 & -2 & 45 & 100 & 30 & 8 & 19 & 13 \\
\hline $\begin{array}{l}\text { 6. New } \\
\text { experience }\end{array}$ & 19 & 27 & 7 & 27 & 31 & 30 & 100 & 13 & 19 & 19 \\
\hline $\begin{array}{l}\text { 7. Seek } \\
\text { adventure }\end{array}$ & 14 & 24 & 19 & 14 & 19 & 8 & 13 & 100 & 37 & 62 \\
\hline $\begin{array}{l}\text { 9. Interconnected } \\
\text { 10. Grow } \\
\text { spiritually }\end{array}$ & 4 & 18 & 12 & -2 & 23 & 19 & 19 & 37 & 100 & 52 \\
\hline $\begin{array}{l}\text { 11. All spiritual } \\
\text { beings }\end{array}$ & 10 & 14 & 23 & 3 & 32 & 13 & 19 & 62 & 52 & 100 \\
\hline
\end{tabular}

Shading key for correlations

\begin{tabular}{|l|l|l|l|l|l|}
\hline $10-19$ & $20-39$ & & $40-59$ & & $60-79$ \\
\hline
\end{tabular}

Figure 5 Patterns of correlations $(\times 100)$ in the first of the confirmatory sub-samples 


\begin{tabular}{|c|c|c|c|}
\hline Female & 53.3 & \multicolumn{2}{|c|}{ How often have you attended before? } \\
\hline Ethnicity & & Never & 80.4 \\
\hline White & 95.1 & Once & 6.9 \\
\hline Other & 4.9 & Either two or three times & 6.6 \\
\hline Activity & & More than three times & 6.1 \\
\hline Employed & 55.2 & \multicolumn{2}{|c|}{ How much do you know about Beltane? } \\
\hline Unemployed & 4.1 & Understand the significance & 23.3 \\
\hline Retired or homemaker & 4.1 & Know a little & 43.2 \\
\hline International student & 12.9 & Heard informally & 33.4 \\
\hline Local student & 23.6 & \multicolumn{2}{|l|}{ Faith } \\
\hline Age & & None & 37.8 \\
\hline Younger than 30 & 59.3 & Christian & 28.6 \\
\hline $30-39$ & 20.8 & Agnostic, atheist, humanist & 16.0 \\
\hline 40 and over & 19.9 & Faith not classified elsewhere & 10.5 \\
\hline Place of residence & & Wiccan or pagan & 7.0 \\
\hline Edinburgh & 51.9 & \multicolumn{2}{|l|}{ With whom did you attend? } \\
\hline Rest of Scotland & 18.6 & Alone & 9.5 \\
\hline Rest of UK & 12.5 & Family group & 10.3 \\
\hline Europe & 11.2 & Friends & 54.2 \\
\hline Other & 5.9 & Partner & 21.7 \\
\hline Birthplace & & Colleagues, other & 4.3 \\
\hline Scotland & 27.0 & \multicolumn{2}{|c|}{$\begin{array}{l}\text { Non-residents' reason for being in } \\
\text { Edinburqh }\end{array}$} \\
\hline Europe & 30.5 & Attend Beltane & 38.0 \\
\hline Rest of UK \& Ireland & 22.6 & Visit family/friends & 17.0 \\
\hline USA or Canada & 11.9 & Leisure & 31.6 \\
\hline Other & 8.1 & Other & 13.5 \\
\hline
\end{tabular}

Table 1a Percentage distribution of characteristics 


\begin{tabular}{|c|c|c|c|c|c|c|c|c|}
\hline \multirow[b]{3}{*}{ New experience } & \multicolumn{5}{|c|}{ Percentages } & \multirow[b]{2}{*}{ Mean } & \multirow[b]{2}{*}{ Std Dev } & \multirow[b]{2}{*}{$\begin{array}{l}\text { Number } \\
\text { missing }\end{array}$} \\
\hline & $\begin{array}{l}\text { Strongly } \\
\text { agree }\end{array}$ & Agree & Neither & Disagree & $\begin{array}{l}\text { Strongly } \\
\text { disagree }\end{array}$ & & & \\
\hline & 55.3 & 36.2 & 4.8 & 2.1 & 1.6 & 1.6 & 0.81 & 1 \\
\hline Know about & 34.6 & 44.1 & 14.1 & 4.8 & 2.4 & 2.0 & 0.95 & 0 \\
\hline Enjoy performance & 65.1 & 29.6 & 3.5 & 0.8 & 1.1 & 1.4 & 0.70 & 0 \\
\hline Increase cultural & 38.9 & 37.6 & 14.9 & 7.2 & 1.3 & 1.9 & 0.97 & 0 \\
\hline Let hair down & 28.5 & 31.7 & 22.1 & 13.3 & 4.3 & 2.3 & 1.2 & 0 \\
\hline Seek adventure & 28.7 & 32.2 & 24.2 & 13.6 & 1.3 & 2.3 & 1.1 & 0 \\
\hline Unpredictable things & 27.9 & 32.2 & 23.6 & 12.3 & 4.0 & 2.3 & 1.1 & 2 \\
\hline Wild behaviour & 24.6 & 24.3 & 22.5 & 21.1 & 7.5 & 2.6 & 1.3 & 1 \\
\hline Relieve boredom & 13.9 & 20.3 & 16.3 & 33.7 & 15.8 & 3.2 & 1.3 & 1 \\
\hline Escape routine & 18.1 & 28.1 & 17.6 & 25.1 & 11.1 & 2.8 & 1.3 & 5 \\
\hline Change of pace & 16.3 & 34.1 & 17.9 & 24.8 & 6.9 & 2.7 & 1.2 & 0 \\
\hline Relieve stress & 12.0 & 24.3 & 19.5 & 31.6 & 12.6 & 3.1 & 1.2 & 1 \\
\hline Be with friends & 42.1 & 35.8 & 5.2 & 11.5 & 5.5 & 2.0 & 1.2 & 9 \\
\hline Attend with group & 40.2 & 34.3 & 13.4 & 9.7 & 2.4 & 2.0 & 1.1 & 2 \\
\hline Meet new people & 38.3 & 44.8 & 8.8 & 7.0 & 1.7 & 1.9 & 0.91 & 2 \\
\hline People enjoying & 53.9 & 38.6 & 5.6 & 1.3 & 0.5 & 1.6 & 0.71 & 2 \\
\hline Interconnected & 37.3 & 38.9 & 16.1 & 5.6 & 2.1 & 2.0 & 0.98 & 2 \\
\hline Grow spiritually & 47.4 & 38.8 & 8.1 & 4.9 & 0.8 & 1.7 & 0.87 & 4 \\
\hline All spiritual beings & 27.9 & 29.2 & 23.2 & 13.7 & 5.9 & 2.4 & 1.2 & 2 \\
\hline Love is at the heart & 21.7 & 26.5 & 21.7 & 18.8 & 11.3 & 2.7 & 1.3 & 2 \\
\hline Nonreligious people & 73.1 & 20.4 & 5.4 & 0.27 & 0.81 & 1.4 & 0.67 & 3 \\
\hline Pain and suffering & 11.6 & 25.5 & 22.3 & 22.6 & 18.0 & 3.1 & 1.3 & 3 \\
\hline
\end{tabular}

Table 1b Summary responses to motivation and spirituality statements 


\begin{tabular}{|lcccc|}
\hline & PA & MAP & VSS & $\begin{array}{c}\text { Eigenvalues } \\
\text { exceeding } \\
\text { one }\end{array}$ \\
Exploratory sub-sets (176 cases) & 2 & 2 & 2 & 4 \\
Motivations only & 3 & 3 & 3 & 5 \\
Motivations and spirituality & 2 & 2 & 2 & 4 \\
Un-imputed data (165 cases) & 3 & 3 & 3 & 5 \\
Motivations only & & & & \\
Motivations and spirituality & & & & \\
\hline
\end{tabular}

Table 2 Number of principal components to extract 


\begin{tabular}{|c|c|c|c|c|c|c|}
\hline & Two & Three & & & & \\
\hline Determinant & 0.0454 & 0.0154 & & & & \\
\hline Bartlett & $531.4^{* * *}$ & $713.1^{* * *}$ & & & & \\
\hline KMO sampling adequacy & 0.803 & 0.757 & & & & \\
\hline Residuals $>0.05$ & $9(42.9 \%)$ & $15.4(34.2 \%)$ & & & & \\
\hline Total explained variance & 70.4 & 69.2 & & & & \\
\hline & $\begin{array}{l}\text { Sampling } \\
\text { adequacy }\end{array}$ & Communality & C1 & $\mathrm{C} 2$ & C3 & $\begin{array}{c}\text { Cronbach } \\
\alpha\end{array}$ \\
\hline Escape from routine life & 0.761 & 0.839 & 0.900 & 0.171 & & 0.877 \\
\hline A change of pace & 0.788 & 0.755 & 0.847 & 0.194 & & \\
\hline Relieve daily stress & 0.875 & 0.707 & 0.823 & 0.175 & & \\
\hline Relieve boredom & 0.870 & 0.634 & 0.795 & 0.0554 & & \\
\hline $\begin{array}{l}\text { Increase cultural } \\
\text { knowledge }\end{array}$ & 0.725 & 0.702 & 0.0738 & 0.835 & & 0.741 \\
\hline Enjoy new experiences & 0.737 & 0.669 & 0.113 & 0.810 & & \\
\hline To seek adventure & 0.830 & 0.619 & 0.242 & 0.749 & & \\
\hline Variance explained & & & 41.6 & 28.8 & & \\
\hline Average communality & & & 0.734 & 0.663 & & \\
\hline Escape from routine life & 0.762 & 0.839 & 0.902 & 0.0390 & 0.153 & 0.877 \\
\hline A change of pace & 0.769 & 0.757 & 0.851 & 0.0502 & 0.176 & \\
\hline Relieve daily stress & 0.841 & 0.707 & 0.822 & 0.0409 & 0.167 & \\
\hline Relieve boredom & 0.869 & 0.636 & 0.793 & -0.0565 & 0.0589 & \\
\hline We are all spiritual beings & 0.676 & 0.680 & 0.0405 & 0.795 & 0.214 & 0.744 \\
\hline All life is interconnected & 0.619 & 0.761 & 0.0420 & 0.864 & 0.113 & \\
\hline Grow spiritually & 0.652 & 0.643 & -0.0303 & 0.801 & 0.0154 & \\
\hline $\begin{array}{l}\text { Increase cultural } \\
\text { knowledge }\end{array}$ & 0.719 & 0.711 & 0.0827 & 0.123 & 0.830 & 0.741 \\
\hline Enjoy new experiences & 0.749 & 0.661 & 0.122 & 0.0547 & 0.802 & \\
\hline To seek adventure & 0.829 & 0.614 & 0.250 & 0.106 & 0.735 & \\
\hline Variance explained & & & 29.0 & 20.5 & 19.8 & \\
\hline Average communality & & & 0.735 & 0.695 & 0.662 & \\
\hline
\end{tabular}




\begin{tabular}{|c|c|c|c|c|c|c|}
\hline Determinant & $\begin{array}{c}\text { Two } \\
\text { components } \\
0.132\end{array}$ & $\begin{array}{c}\text { Three } \\
\text { components } \\
0.0576\end{array}$ & & & & \\
\hline Bartlett & $384.3^{* * *}$ & $553.1^{* * *}$ & & & & \\
\hline KMO sampling adequacy & 0.752 & 0.738 & & & & \\
\hline Residuals $>0.05$ & $12(57.1 \%)$ & $17.8(39.6 \%)$ & & & & \\
\hline Total explained variance & 61.7 & 62.8 & & & & \\
\hline & $\begin{array}{l}\text { Sampling } \\
\text { adequacy }\end{array}$ & Communality & C1 & $\mathrm{C} 2$ & C3 & $\begin{array}{c}\text { Cronbach } \\
\alpha\end{array}$ \\
\hline Escape from routine life & 0.711 & 0.789 & 0.883 & 0.0957 & & 0.829 \\
\hline A change of pace & 0.760 & 0.649 & 0.760 & 0.266 & & \\
\hline Relieve daily stress & 0.861 & 0.633 & 0.796 & 0.00087 & & \\
\hline Relieve boredom & 0.763 & 0.604 & 0.768 & 0.117 & & \\
\hline $\begin{array}{l}\text { Increase cultural } \\
\text { knowledge }\end{array}$ & 0.706 & 0.573 & 0.163 & 0.739 & & 0.570 \\
\hline Enjoy new experiences & 0.617 & 0.624 & -0.0570 & 0.788 & & \\
\hline To seek adventure & 0.801 & 0.446 & 0.196 & 0.639 & & \\
\hline Variance explained & & & 37.9 & 23.9 & & \\
\hline Average communality & & & 0.669 & 0.548 & & \\
\hline Escape from routine life & 0.718 & 0.795 & 0.886 & 0.0466 & 0.0881 & 0.829 \\
\hline A change of pace & 0.761 & 0.646 & 0.755 & 0.114 & 0.253 & \\
\hline Relieve daily stress & 0.853 & 0.634 & 0.770 & 0.201 & -0.0237 & \\
\hline Relieve boredom & 0.751 & 0.626 & 0.782 & -0.0183 & 0.115 & \\
\hline We are all spiritual beings & 0.638 & 0.750 & 0.0826 & 0.853 & 0.126 & 0.710 \\
\hline All life is interconnected & 0.700 & 0.634 & 0.174 & 0.776 & -0.0346 & \\
\hline Grow spiritually & 0.748 & 0.549 & -0.0111 & 0.715 & 0.194 & \\
\hline $\begin{array}{l}\text { Increase cultural } \\
\text { knowledge }\end{array}$ & 0.719 & 0.562 & 0.157 & 0.192 & 0.707 & 0.570 \\
\hline Enjoy new experiences & 0.658 & 0.630 & -0.0430 & 0.0240 & 0.792 & \\
\hline To seek adventure & 0.830 & 0.451 & 0.204 & 0.0635 & 0.636 & \\
\hline Variance explained & & & 26.6 & 19.4 & 16.7 & \\
\hline Average communality & & & 0.675 & 0.644 & 0.548 & \\
\hline
\end{tabular}

Significant at better than 0.001

Table 4 Averages over generalisable sub-samples of size 199 


\begin{tabular}{|c|c|c|c|}
\hline Diagnostic & Benchmark & Value & \\
\hline Chi-square & & 35.7 & \\
\hline Degrees of freedom & & 30 & \\
\hline Probability of Chi-sq & $>0.05$ & 0.219 & \\
\hline RMSEA & $<0.06$ & 0.0310 & \\
\hline $\mathrm{Cl}$ upper limit & $\leq 0.07$ & 0.0647 & \\
\hline Tucker-Lewis NNFI & $\geq 0.95$ & 0.984 & \\
\hline Bentler CFI & $\geq 0.95$ & 0.989 & \\
\hline SRMR & $<0.08$ & 0.0475 & \\
\hline Factor & Item & Loading & $z$ \\
\hline \multirow[t]{4}{*}{ Escape } & Relieve boredom & 0.718 & $10.47^{* *}$ \\
\hline & Escape routine & 0.865 & $13.86^{* *}$ \\
\hline & Change of pace & 0.724 & $10.24^{* *}$ \\
\hline & Relieve stress & 0.665 & $10.04^{* *}$ \\
\hline \multirow[t]{3}{*}{ Spirituality } & Interconnected & 0.626 & $8.12^{* *}$ \\
\hline & Grow spiritually & 0.539 & $7.07^{* *}$ \\
\hline & All spiritual beings & 0.871 & $10.72^{* *}$ \\
\hline \multirow[t]{3}{*}{ Cultural adventure } & New experience & 0.498 & $5.75^{\star *}$ \\
\hline & Seek adventure & 0.487 & $5.64^{* *}$ \\
\hline & Increase cultural & 0.686 & $7.47^{* *}$ \\
\hline Factor $^{a}$ & Covariance with & & \\
\hline \multirow[t]{2}{*}{ Spirituality } & Escape & 0.219 & $2.68^{* *}$ \\
\hline & Cultural adventure & 0.394 & $4.23^{* *}$ \\
\hline Escape & Cultural adventure & 0.335 & $3.56^{* *}$ \\
\hline Error correlation & $\begin{array}{l}\text { Change of pace \& } \\
\text { Relieve boredom }\end{array}$ & -0.152 & $-3.26^{\star *}$ \\
\hline $\begin{array}{l}\text { Cross-loading } \\
\text { Cultural adventure }\end{array}$ & Change of pace & 0.173 & $240^{*}$ \\
\hline
\end{tabular}

${ }^{* *}\left({ }^{*}\right)$ denotes significance at better than one (five) per cent.

Table 5 CFA results in the first generalisable sub-sample of size 199 


\section{BELTANE FIRE FESTIVAL SURVEY 2011}

We are undertaking a study on why people attend the Beltane Fire Festival on behalf of the festival organisers and QMU. This questionnaire will only take a few minutes of your time and will be STRICTLY CONFIDENTIAL.

1. Where is your place of residence?

2. If not from Edinburgh, what is the main reason you came? (Underline as applicable, if more than one)

Beltane Business

Visiting friends/relatives

Leisure

Other

3. Who did you come to Beltane with?

$\begin{array}{lll}\text { Alone } & \text { Partner } & \text { Colleagues } \\ \text { Family group } & \text { Friends } & \text { Other }\end{array}$

4. Have you attended the Beltane before? YES/NO. (Underline one) If yes, go to Q5. If no, go to Q6.
5. How many times have you attended Beltane?

6. What is your reason for attending the Betlane?

\section{How much do you know about the Beltane (Circle} one):

a. I understand the significance of what happens at Beltane; b. I know a little about what happens and want to understand better; or

c. I have heard informally about Beltane and am curious to know what happens.

8. Please indicate your agreement with the following statements as they relate to your reason for attending Beltane (Circle one for each statement):

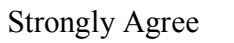

$\begin{array}{ccc}\text { Strongly Agree } & \text { Agree } & \begin{array}{c}\text { Neither Agree/ } \\ \text { nor Disagree }\end{array} \\ 1 & 2 & 3 \\ 1 & 2 & 3 \\ 1 & 2 & 3 \\ 1 & 2 & 3 \\ 1 & 2 & 3 \\ 1 & 2 & 3 \\ 1 & 2 & 3 \\ 1 & 2 & 3 \\ 1 & 2 & 3 \\ 1 & 2 & 3 \\ 1 & 2 & 3 \\ 1 & 2 & 3 \\ 1 & 2 & 3 \\ 1 & 2 & 3 \\ 1 & 2 & 3 \\ 1 & 2 & 3\end{array}$

$\begin{array}{lc}\text { Disagree } & \begin{array}{c}\text { Strongly } \\ \text { Disagree }\end{array} \\ 4 & 5 \\ 4 & 5 \\ 4 & 5 \\ 4 & 5 \\ 4 & 5 \\ 4 & 5 \\ 4 & 5 \\ 4 & 5 \\ 4 & 5 \\ 4 & 5 \\ 4 & 5 \\ 4 & 5 \\ 4 & 5 \\ 4 & 5 \\ 4 & 5 \\ 4 & 5\end{array}$

9. Rate yourself on each of the following traits as compared with the average person your age. We want the most accurate estimate of how you see yourself (Mark one in each row):

$\begin{array}{llllll} & \text { Highest (10\%) } & \text { Above average } & \text { Average } & \text { Below Average } & \text { Lowest }(10 \%) \\ \text { a. Artistic ability } & 1 & 2 & 3 & 4 & 5 \\ \text { b. Creativity } & 1 & 2 & 3 & 4 & 5 \\ \text { c. Forgiveness } & 1 & 2 & 3 & 4 & 5 \\ \text { d. Generosity } & 1 & 2 & 3 & 4 & 5 \\ \text { e. Kindness } & 1 & 2 & 3 & 4 & 5 \\ \text { f. Spirituality } & 1 & 2 & 3 & 4 & 5\end{array}$

10. Please indicate your agreement with each of the following statements (circle one for each statement):

\begin{tabular}{|c|c|c|c|}
\hline Strongly Agree & Agree & $\begin{array}{l}\text { Neither Agree/ } \\
\text { nor Disagree }\end{array}$ & Disagree \\
\hline
\end{tabular}

a. Love is at the root of all great religions

b. All life is interconnected

c. We are all spiritual beings

d. Most people can grow spiritually

without being religious

e. Non-religious people can live lives just as moral as those of religious believers

f. Pain and suffering are essential to becoming a better person nor Disagree 
11. Do you agree with this statement: I consider myself to be on a spiritual quest (underline one) Yes No Not sure

12. Please indicate the extent to which you are searching for meaning/purpose in life (mark one)

To a great extent

\section{DEMOGRAPHIC INFORMATION (final section)}

13. Gender (Underline one):

Male Female Other

14. What is your age? (Underline one)

$\begin{array}{ll}\text { Under } 18 & 18-20 \\ 21-24 & 25-29 \\ 30-34 & 35-39 \\ 40-44 & 45-49 \\ 50-54 & 55-59\end{array}$

60 or over

15a. What is your occupation?

(If student go to Q15b, if not go to Q15c)

15b. If you answered student, are you attending

(Underline one, then go to Q17):

School College

University Other

15c If you responded an occupation other than student, what is your highest level of qualification? (Underline

one)

Degree or above

Trade qualification

Diploma/Certificate

Other

16. What is your employment status? (Underline one)

Employed F/T Employed P/T

Unemployed Self-employed

Retired Home-maker

17. My birthplace is? (Underline one)

Scotland

N.lreland

England

Wales

US or Canada

Ireland

Europe

Other

18. What is your ethnicity? (Underline one)

White - UK White - Other

Asian - Bangladeshi, Indian or Pakistani

Asian - Chinese Asian - Other

Black

Carribean

Black - Other

Other

19. What is your religious/faith preference? (Underline1)

None

Catholic

Church of Scotland

Orthodox

Buddhist

Hindu

Islamic

Other Christian

Jewish

Atheist

Humanist
To some extent

Not at all

3

Pagan Other

20. We would like to do a short follow up survey on your experiences of the Beltane festival. Would it be okay to email you at a later date (your email address would not be used for any other purpose)?

Email address: 
Appendix 2 Congruence coefficients

\begin{tabular}{|c|c|c|c|c|c|c|}
\hline $\begin{array}{c}\text { MI sample } \\
1\end{array}$ & $\begin{array}{l}\text { Which sub- } \\
\text { samples? } \\
\text { E \& E }\end{array}$ & Escape & $\begin{array}{c}\text { Cultural } \\
\text { adventure } \\
0.350\end{array}$ & $\begin{array}{c}\text { Escape } \\
\text { Spirituality }\end{array}$ & $\begin{array}{c}\text { Spirituality } \\
0.106\end{array}$ & $\begin{array}{c}\text { Cultural } \\
\text { adventure } \\
0.340 \\
0.244\end{array}$ \\
\hline 1 & $G \& G$ & Escape & 0.269 & $\begin{array}{l}\text { Escape } \\
\text { Spirituality }\end{array}$ & 0.220 & $\begin{array}{l}0.258 \\
0.244\end{array}$ \\
\hline 2 & $E \& E$ & Escape & 0.344 & $\begin{array}{c}\text { Escape } \\
\text { Spirituality }\end{array}$ & 0.108 & $\begin{array}{l}0.338 \\
0.246\end{array}$ \\
\hline 2 & $G \& G$ & Escape & 0.273 & $\begin{array}{c}\text { Escape } \\
\text { Spirituality }\end{array}$ & 0.224 & $\begin{array}{l}0.259 \\
0.241\end{array}$ \\
\hline 3 & $E \& E$ & Escape & 0.349 & $\begin{array}{l}\text { Escape } \\
\text { Spirituality }\end{array}$ & 0.110 & $\begin{array}{l}0.339 \\
0.247\end{array}$ \\
\hline 3 & $G \& G$ & Escape & 0.269 & $\begin{array}{l}\text { Escape } \\
\text { Spirituality }\end{array}$ & 0.212 & $\begin{array}{l}0.258 \\
0.243\end{array}$ \\
\hline 4 & $E \& E$ & Escape & 0.349 & $\begin{array}{l}\text { Escape } \\
\text { Spirituality }\end{array}$ & 0.101 & $\begin{array}{l}0.339 \\
0.241\end{array}$ \\
\hline 4 & $G \& G$ & Escape & 0.282 & $\begin{array}{l}\text { Escape } \\
\text { Spirituality }\end{array}$ & 0.209 & $\begin{array}{l}0.268 \\
0.234\end{array}$ \\
\hline 5 & $E \& E$ & Escape & 0.349 & $\begin{array}{l}\text { Escape } \\
\text { Spirituality }\end{array}$ & 0.104 & $\begin{array}{l}0.340 \\
0.241\end{array}$ \\
\hline 5 & $G \& G$ & Escape & 0.281 & $\begin{array}{c}\text { Escape } \\
\text { Spirituality }\end{array}$ & 0.208 & $\begin{array}{l}0.270 \\
0.239 \\
\end{array}$ \\
\hline Average & & Escape & 0.348 & $\begin{array}{c}\text { Escape } \\
\text { Spirituality }\end{array}$ & 0.106 & $\begin{array}{l}0.339 \\
0.244\end{array}$ \\
\hline & & Escape & 0.275 & $\begin{array}{l}\text { Escape } \\
\text { Spirituality }\end{array}$ & 0.215 & $\begin{array}{l}0.263 \\
0.240\end{array}$ \\
\hline
\end{tabular}

E: exploratory sub-sample; G: generalisable sub-sample

Table A2a Congruence for factors obtained in the same sub-samples 


\begin{tabular}{|c|c|c|c|c|c|c|c|c|}
\hline \multirow[t]{2}{*}{ MI sample } & \multirow{2}{*}{$\begin{array}{c}\text { Sub- } \\
\text { sample }\end{array}$} & \multicolumn{4}{|c|}{ Generalisable } & \multicolumn{3}{|c|}{ Generalisable } \\
\hline & & & Escape & $\begin{array}{l}\text { Cultural } \\
\text { adventure }\end{array}$ & & & Spirituality & $\begin{array}{l}\text { Cultural } \\
\text { adventure }\end{array}$ \\
\hline \multirow[t]{3}{*}{1} & & Escape & 0.993 & 0.308 & Escape & 0.989 & 0.167 & 0.298 \\
\hline & Exploratory & $\mathrm{CA}$ & 0.318 & 0.986 & Spirituality & 0.157 & 0.992 & 0.241 \\
\hline & & & & & $\mathrm{CA}$ & 0.311 & 0.264 & 0.962 \\
\hline \multirow[t]{3}{*}{2} & & Escape & 0.993 & 0.324 & Escape & 0.983 & 0.170 & 0.289 \\
\hline & Exploratory & CA & 0.301 & 0.986 & Spirituality & 0.160 & 0.992 & 0.238 \\
\hline & & & & & CA & 0.310 & 0.264 & 0.964 \\
\hline \multirow[t]{3}{*}{3} & & Escape & 0.993 & 0.308 & Escape & 0.983 & 0.168 & 0.299 \\
\hline & Exploratory & CA & 0.317 & 0.986 & Spirituality & 0.155 & 0.992 & 0.239 \\
\hline & & & & & CA & 0.309 & 0.265 & 0.965 \\
\hline \multirow[t]{3}{*}{4} & & Escape & 0.992 & 0.320 & Escape & 0.982 & 0.161 & 0.303 \\
\hline & Exploratory & $\mathrm{CA}$ & 0.318 & 0.986 & Spirituality & 0.148 & 0.992 & 0.232 \\
\hline & & & & & $\mathrm{CA}$ & 0.314 & 0.261 & 0.963 \\
\hline \multirow[t]{3}{*}{5} & & Escape & 0.993 & 0.316 & Escape & 0.982 & 0.461 & 0.305 \\
\hline & Exploratory & $\mathrm{CA}$ & 0.322 & 0.987 & Spirituality & 0.151 & 0.992 & 0.235 \\
\hline & & & & & $\mathrm{CA}$ & 0.315 & 0.260 & 0.965 \\
\hline \multirow[t]{3}{*}{ Ave } & & Escape & 0.993 & 0.315 & Escape & 0.984 & 0.225 & 0.299 \\
\hline & Exploratory & CA & 0.315 & 0.986 & Spirituality & 0.154 & 0.992 & 0.237 \\
\hline & & & & & CA & 0.312 & 0.263 & 0.964 \\
\hline
\end{tabular}

Table A2b Congruence for components across exploratory and generalisable sub-samples

Critical values at the five per cent level of significance for the congruence coefficients are 0.973 for five degrees of freedom (that is, testing structures with seven items in two components) and 0.817 for eight degrees of freedom (that is, testing structures with 11 items in three components). See Bedeian, Armenakis and Randolph (1988). Coefficients in bold type are significant at five per cent or better. 